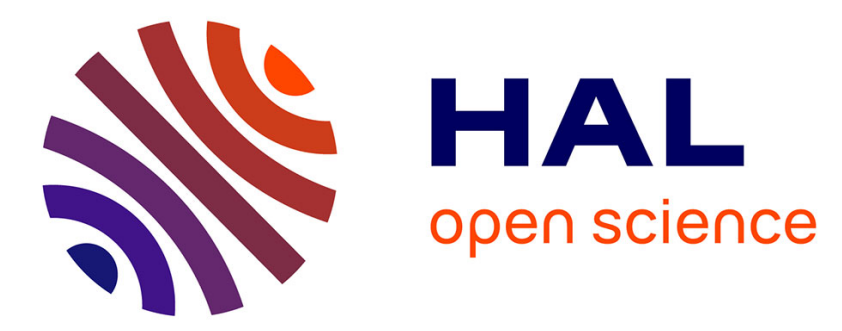

\title{
Plastic particle ingestion by wild freshwater fish: a critical review
}

France Collard, Johnny Gasperi, Geir Wing Gabrielsen, Bruno Tassin

\section{To cite this version:}

France Collard, Johnny Gasperi, Geir Wing Gabrielsen, Bruno Tassin. Plastic particle ingestion by wild freshwater fish: a critical review. Environmental Science and Technology, 2019, 31, 10.1021/acs.est.9b03083 . hal-02342839

\section{HAL Id: hal-02342839 \\ https://hal-enpc.archives-ouvertes.fr/hal-02342839}

Submitted on 1 Nov 2019

HAL is a multi-disciplinary open access archive for the deposit and dissemination of scientific research documents, whether they are published or not. The documents may come from teaching and research institutions in France or abroad, or from public or private research centers.
L'archive ouverte pluridisciplinaire HAL, est destinée au dépôt et à la diffusion de documents scientifiques de niveau recherche, publiés ou non, émanant des établissements d'enseignement et de recherche français ou étrangers, des laboratoires publics ou privés. 
Subscriber access provided by Ecole des Ponts ParisTech

\title{
Critical Review
}

\section{Plastic particle ingestion by wild freshwater fish: a critical review}

\author{
France Collard, Johnny Gasperi, Geir Wing Gabrielsen, and Bruno Tassin
}

Environ. Sci. Technol., Just Accepted Manuscript • DOI: 10.1021/acs.est.9b03083 • Publication Date (Web): 30 Oct 2019

Downloaded from pubs.acs.org on October 31, 2019

\section{Just Accepted}

"Just Accepted" manuscripts have been peer-reviewed and accepted for publication. They are posted online prior to technical editing, formatting for publication and author proofing. The American Chemical Society provides "Just Accepted" as a service to the research community to expedite the dissemination of scientific material as soon as possible after acceptance. "Just Accepted" manuscripts appear in full in PDF format accompanied by an HTML abstract. "Just Accepted" manuscripts have been fully peer reviewed, but should not be considered the official version of record. They are citable by the Digital Object Identifier (DOI@). "Just Accepted" is an optional service offered to authors. Therefore, the "Just Accepted" Web site may not include all articles that will be published in the journal. After a manuscript is technically edited and formatted, it will be removed from the "Just Accepted" Web site and published as an ASAP article. Note that technical editing may introduce minor changes to the manuscript text and/or graphics which could affect content, and all legal disclaimers and ethical guidelines that apply to the journal pertain. ACS cannot be held responsible for errors or consequences arising from the use of information contained in these "Just Accepted" manuscripts. 
5 France Collard ${ }^{* 1,2}$, Johnny Gasperi ${ }^{1,3}$, Geir W. Gabrielsen ${ }^{2}$, Bruno Tassin ${ }^{1}$

6

7 'Laboratoire Eau Environnement et Systèmes urbains (LEESU), Université Paris-Est Créteil, 861 avenue du Général de Gaulle, 94010 Cedex Créteil, France.

$9 \quad{ }^{2}$ Norwegian Polar Institute, Fram Centre, NO-9296 Tromsø, Norway.

${ }^{3}$ Water and Environment Laboratory (LEE), Geotechnical engineering, Environment, Natural hazards and Earth Sciences Department (GERS), French Institute of Science and Technology for Transport, Development and Networks (IFSTTAR), IRSTV, 44340 Bouguenais, France.

*Corresponding author:

francecollard16@gmail.com

17 phone: +4777750655

18 Current address:

19 Norwegian Polar Institute

20 Research Department 


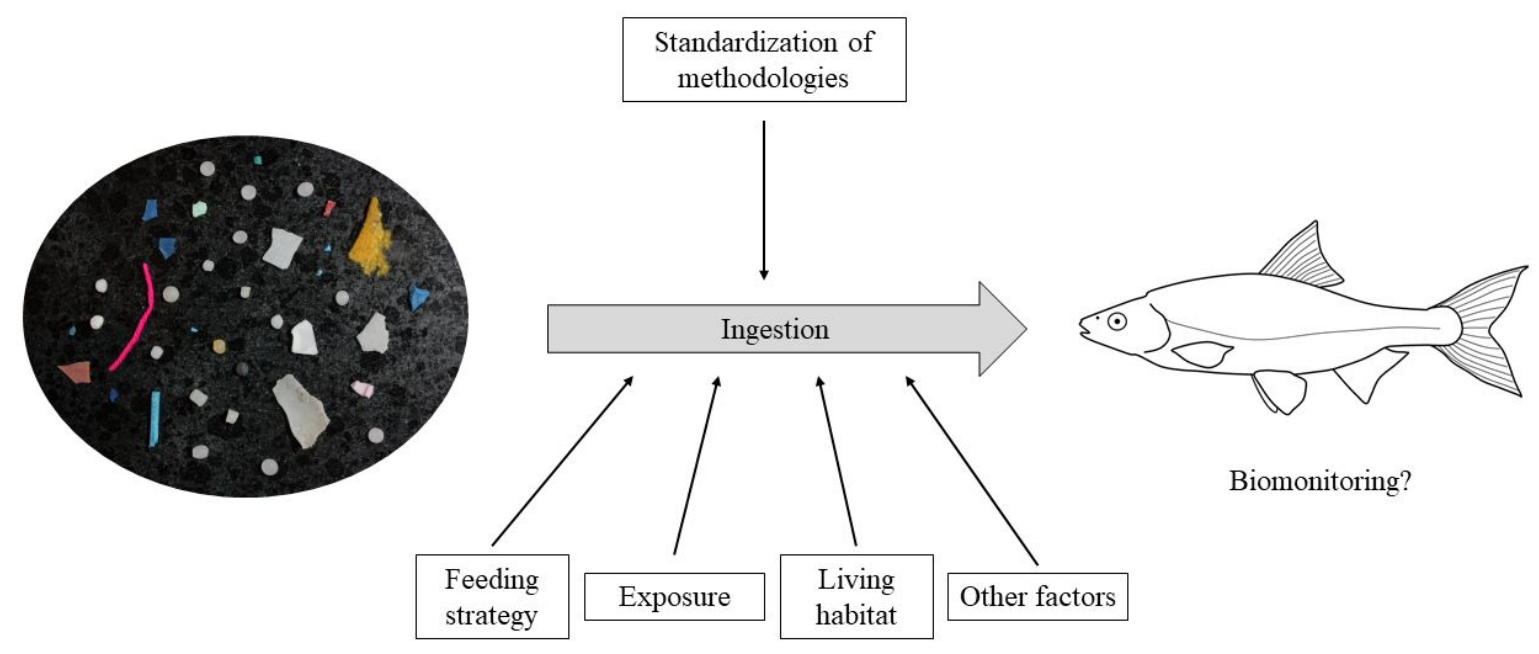

27 
Abstract

Plastic pollution, especially microplastics (MP) pollution, is a hot topic in both mainstream media and scientific literature. Although rivers are potentially the major transport pathway of this pollution to the sea, plastic contamination in freshwater bodies is comparatively understudied. Microplastic pollution in freshwater fish is of growing interest, and while few studies exist, discrepancies do occur in the sampling, extraction, and identification of MP and in the expression of the results. Even though those differences hamper comparisons between some studies, a comparative work has been performed to identify the factors influencing MP ingestion by fish and consequently to target potential ecological traits that can be used to monitor species. Monitoring plastic ingested by fish will give relevant ecological information on MP pollution. This review focuses on MP ingestion by wild freshwater and estuarine fish. In addition to providing an overview of the existing data concerning contamination levels in wild freshwater fish, we aimed to (1) propose several overall recommendations on the methodologies applicable to all biota, (2) compare MP contamination levels in fish and in their environment, and (3) determine which parameters could help to define fish species for monitoring.

\section{Introduction}

Due to their exponentially increasing production since the $1950 \mathrm{~s},{ }^{1}$ plastic materials are polluting all types of environments: marine surface waters, ${ }^{2,3}$ deep-sea sediments, ${ }^{4,5}$ arctic sea ice, ${ }^{6,7}$ soils, ${ }^{8}$ and even air. ${ }^{9,10}$ As an expected and direct consequence, the number of species or taxa exposed to plastic pollution is alarming. ${ }^{11}$ Plastic pieces of all sizes are found in the 
environment, and thus are ingested by many different organisms: marine mammals, ${ }^{12-14}$ marine and terrestrial birds, ${ }^{15-17}$ crustaceans,${ }^{18,19}$ worms, ${ }^{20}$ and fish. ${ }^{21-23}$ Scientific research is currently more focused on the marine environment. The reasons for this focus are probably due the high economic value of marine resources and abundant funding allocated to marine research and monitoring. In particular, microplastics (MP), which are plastic pieces with sizes less than 5 $\mathrm{mm},{ }^{24}$ are well known to pollute seas and oceans. Numerous laboratory studies have shown that this exposure leads to plastic ingestion by various organisms and is associated with some negative impacts, ${ }^{25}$ such as neurotoxicity, ${ }^{26}$ a change in swimming behavior ${ }^{27}$ and reduction of predatory performances. $^{28}$

Human populations are closely linked to water from both marine and freshwater sources. A considerable fraction of the human population lives in the near-coastal zone. ${ }^{29}$ Approximately half of the world's population lives within $3 \mathrm{~km}$ of a freshwater body and only $10 \%$ of the population lives farther than $10 \mathrm{~km}$ away. ${ }^{30}$ However, given that proximity, between 1.15 and 2.41 million tons of plastics are released into the oceans via rivers each year. ${ }^{31}$ Conventional wastewater treatment plants may act as an MP source to rivers, ${ }^{32,33}$ and inappropriate waste management ${ }^{34}$ combined with a high population density ${ }^{35}$ may both be positively correlated with riverine plastic loads.

Increasing number of studies have revealed that freshwaters are contaminated, sometimes largely by plastic, regardless of its size. ${ }^{36-39}$ The number of studies about MP pollution and its impacts is growing (in March 2019, searching the Web of Science for "plastic marine pollution" returned 3 results in 2000 and 351 results in 2018), but a small number of these studies deal with a freshwater environment ( 0 out of the 3 results found in 2000 and 42 out of the 351 results found in 2018). The same observation can be made for fish; searching the Web of Science for the keywords "fish plastic pollution" gave 4 results in 2000 and 99 in 2018, in which 0 and 10 results concern freshwaters, respectively. Despite the large amounts of plastic debris input into 
seas and oceans by rivers, the interactions between these debris and the biota of these ecosystems are poorly studied. Nevertheless, some discrepancies in performed protocols do occur. Among others, the sampling size is frequently too small, and MP identification often relies on visual sorting. In addition, the results are reported in one or two units while at least three are used in publications. Those discrepancies lead to difficulties in comparing data.

Fish are the main taxa studied with regard to MP ingestion in freshwater environments ${ }^{40}$ and constitute an economically, ecologically and highly diversified group. ${ }^{41,42}$ Microplastic ingestion by freshwater fish has been studied worldwide, but these studies have although focused on limited regions (Fig. 1) in comparison with the studies of plastic ingested by wild marine fish. ${ }^{43}$ In total, the studies focusing on freshwater fish, while few, have described MP ingestion by more than 200 species. This large number indicates that some studies have collected few samples. Few published papers have studied the interactions between MP and freshwater biota compared to the number of marine studies, although scientific interest in MP ingestion by freshwater fish is rising. We thus believe that a summary of recommendations for the methods and expression of results and factors leading to MP ingestion by freshwater fish would be useful for the scientific community, especially regarding monitoring. Three main factors have been investigated: the MP levels in abiotic compartments, the living habitat and the feeding strategy. Other factors could have been reviewed, but there are too few studies to allow for a reliable discussion. Exposure through abiotic compartments could be directly correlated with the ingestion of MP. As further discussed in this review, MP ingestion does not always depend on abiotic compartment exposure. Additionally, there is not a clear relationship between MP ingestion and the living habitat and feeding strategy. Some studies have found that benthic or demersal fish ingested more MP, ${ }^{44,45}$ while others reported the contrary. ${ }^{22}$

Monitoring and assessment are essential steps towards addressing specific questions about marine litter, including MP. Monitoring and assessment are needed to assess the state or level 
of pollution and provide objective information to design mitigation measures as well as assess their effectiveness and promote adaptive management. ${ }^{46}$ Recommendations for defining indicator fish species are very few but crucial to improve the comparability between studies.

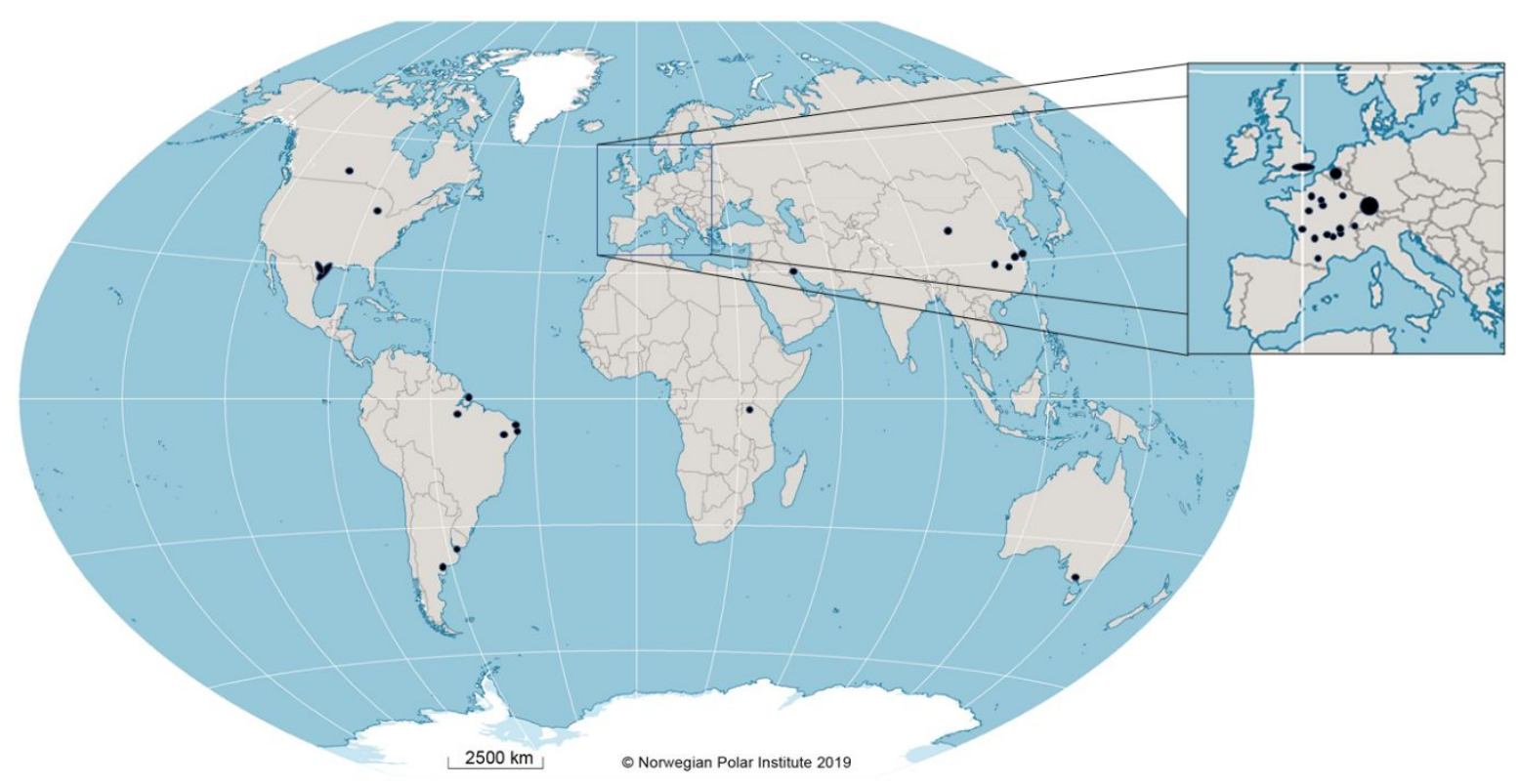

Figure 1. Global overview of the studies performed on MP ingestion by wild freshwater fish.

In this critical review, we aim to (1) propose several recommendations for the harmonization of methodologies, which is applicable not only to MP contamination in freshwater fish studies but also to all biota, (2) compare MP contamination levels in fish and their environment, and subsequently (3) determine which parameters could help to define fish species for monitoring. Our work is based on the occurrence of MP in the guts of fish. The translocation of plastic particles to other organs is beyond the scope of this review but should be considered in further studies. 
2. Methodologies for the study of MP contamination in fish guts

120

121

122

Globally, studies on MP ingestion by fish, both marine and freshwater, follow a general pattern regarding their methodology, which include sampling, gut content (GC) extraction, MP extraction (visual sorting or chemical treatment, which is not always performed), and identification (including spectroscopic analyses which are not always performed). No specific method has been defined as the method to be used in fish GC analyses. In addition, this general pattern is not specific to studies about fish, as it is also used for other organisms or even for water or sediment matrices. In the two latter cases, density separation is often chosen to carry out the MP extraction. Whatever the matrix, discrepancies in methodologies occur, including in the study of MP in the GCs of wild freshwater fish. There are variations in all the steps used to extract and identify MP. In the next sections, we highlight the main issues of the key protocol steps used to extract MP from GCs (Fig. 2) and propose some recommendations to increase the comparability of studies for future research. We will discuss the following main steps: the sampling, extraction, and identification of MP and the expression of the results. Within those steps, we highlight some parameters that we think are of great importance including the sampling size, method for digesting the GCs, definition of the size threshold for the extracted particles, spectroscopic analyses, and the way results are provided. In addition, some recommendations for preventing and evaluating the contamination will be proposed. We selected the most important criteria, as other reviews have already focused on methodologies for the sampling, extraction and analyses of MP in biota or abiotic compartments. ${ }^{40,47,48}$ 


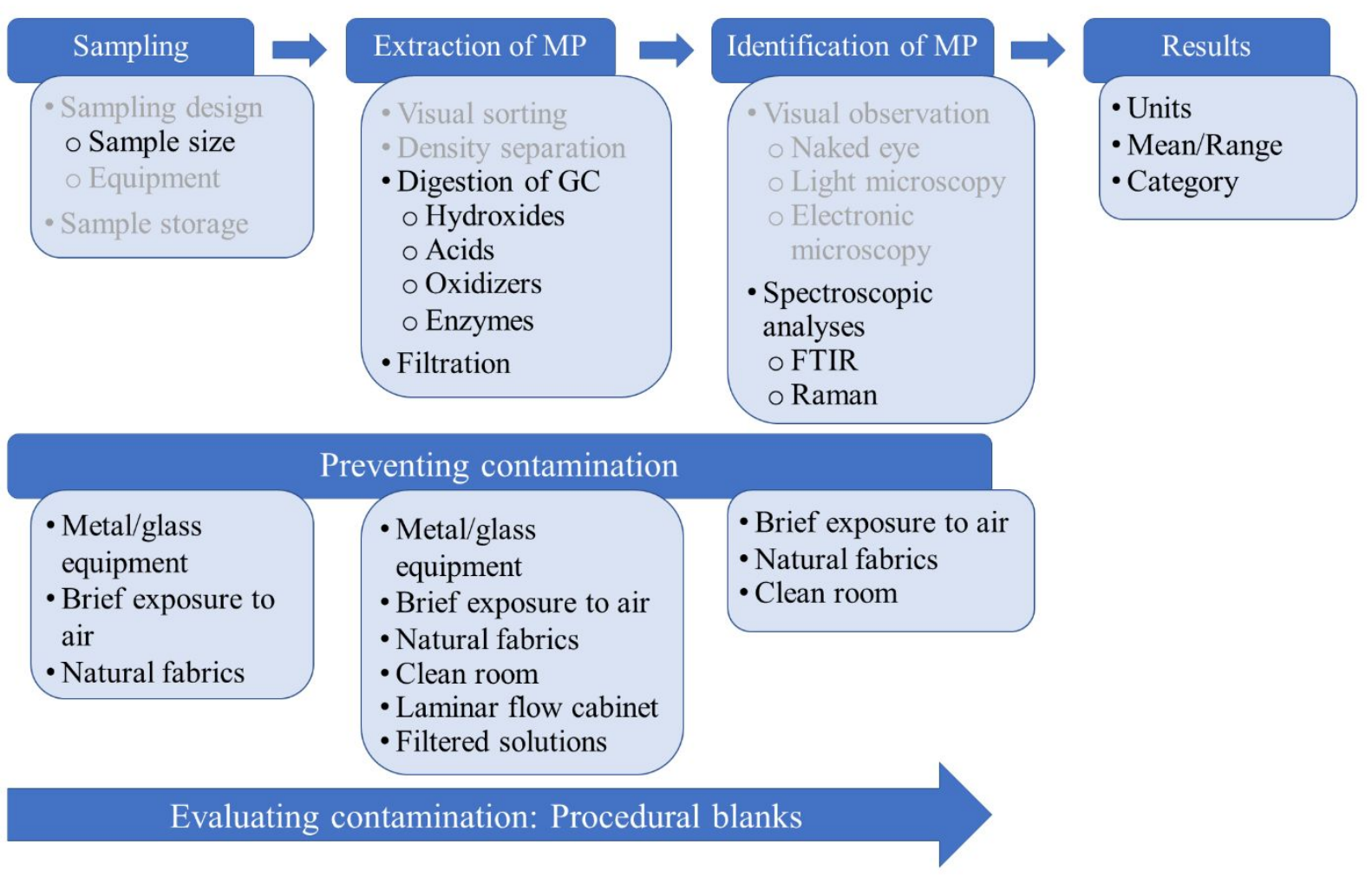

Figure 2. Flowchart of the main steps used to analyze microplastics in fish gut contents. The steps shown in black are discussed in this review. GCs: gut contents, FTIR: Fourier transform infrared.

Among all the species studied, more than twenty have been analyzed at least twice, and most of these species have been studied thanks to studies conducted in South America. ${ }^{49-52}$ In addition, when considering a sampling of at least 10 individuals per species, only seven out of twenty species can be spatially compared. A review focusing on wild marine fish found that the detection of plastic ingestion was positively correlated with an increased sample size (up to $\mathrm{n}=10) .{ }^{43}$ In many studies reviewed here, the number of individuals representing each species was low $(\mathrm{n}<10)$, which is obviously too small to define solid trends in MP contamination. In several publications, data were given for one or two individuals, limiting the representativeness. 
156 Given that a single dataset is available and the number of fish sampled is usually low for most

157

158

159

160

161

162

163

164

165

166

167 studied species, very local one-time events may influence the results and impair the global understanding of MP ingestion by fish. A large sample size is highly important since it will provide enough data to perform reliable statistical analyses. Previously, a threshold of 50 individuals has been defined as sufficiently reliable regarding to achieve statistical power, ${ }^{48,53,54}$ while 40 specimens were considered to be an adequate sample size for the monitoring of plastic ingestion by northern fulmars. ${ }^{55}$ Fig. 3 shows that most studies did not sample more than 50 specimens per species. This chart highlights the need for a better sampling design to statistically support the results.

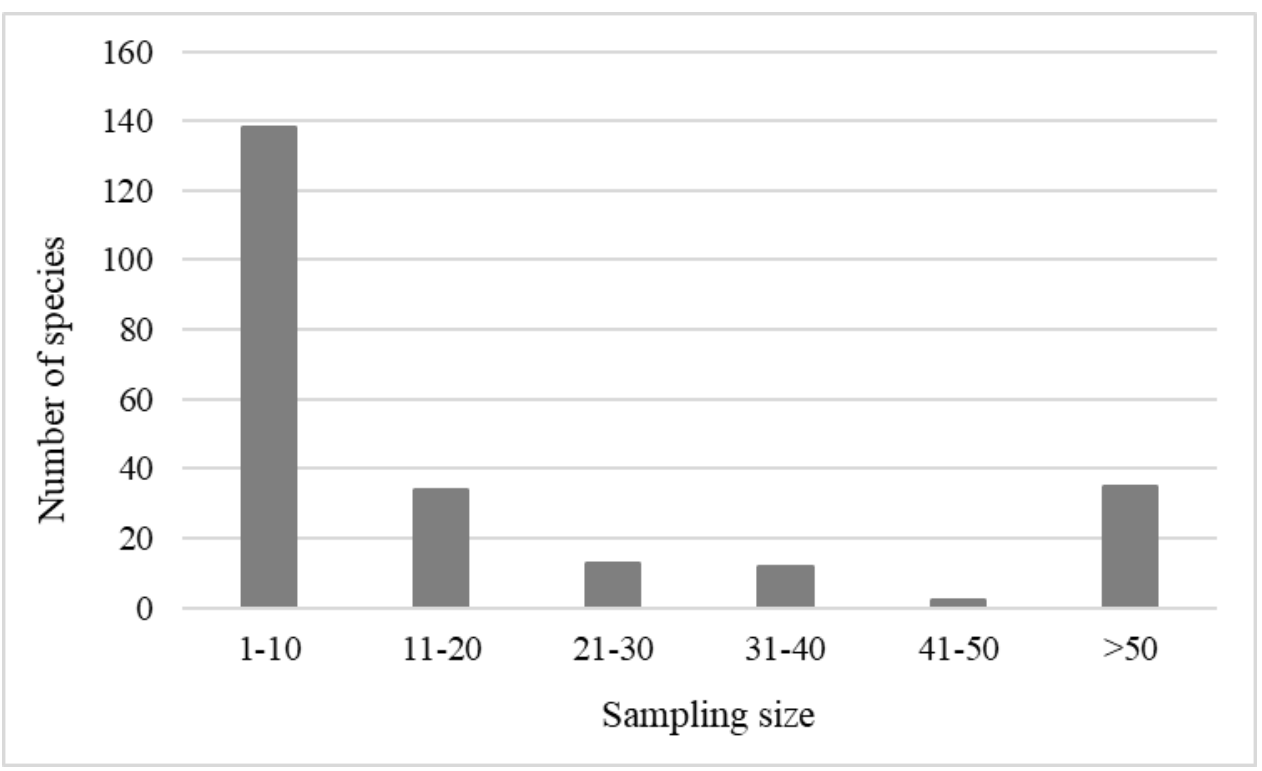

Figure 3. Number of species for each category of sampling size. This chart is based on studies shown in Table 1.

\subsection{Extraction of MP: Digestion of fish gut contents}

The digestion of organic matter is not mandatory but recommended, ${ }^{46}$ especially when aiming to isolate MP from biota. Several methods exist regarding GCs, which are indiscriminate for 
marine and freshwater fish species. Fig. 4 shows that when present, the most common agents are oxidizers (e.g., $\mathrm{H}_{2} \mathrm{O}_{2}$ and $\left.\mathrm{NaClO}\right)^{44,56,57}$ and hydroxides (e.g., $\left.\mathrm{KOH}\right) .{ }^{58,59}$ No studies reported acids as the main digesting agent, which is most likely because acids alter some polymers, such as polyethylene terephthalate (PET), high density polyethylene (HDPE) and polyamide (PA). Acids can also lead to suboptimal digestion. ${ }^{58,60-62}$ Remarkably, to our knowledge, no studies have used enzymes as digesting agents yet. While the efficiency of such agents has been assessed, ${ }^{62-64}$ the cost and duration of this treatment might discourage researchers. Recently, von Friesen et al. ${ }^{65}$ proposed a protocol more efficient than that using $\mathrm{KOH}$ with the convenient advantages of being less time-consuming and commercially available at a low price. This protocol has been thoroughly tested using bivalves but suits a broader range of organisms according to the authors. No studies on fish GCs have used Fenton's agent either, which is probably due to the efficiency of the previously cited methods. This agent does not affect plastic polymers and reduces the sample preparation time. ${ }^{66}$ Both enzymes and Fenton's agent could be a solution to achieving the efficient, rapid and inexpensive digestion of the organic matter in the GCs of freshwater fish but could probably also be used in other biological matrices such as the liver. Some GCs can be very fatty and challenging to digest. No study has identified a means of treating those samples properly. Finding an easy way to process fatty GCs would be useful for further research on fish gut contamination. 


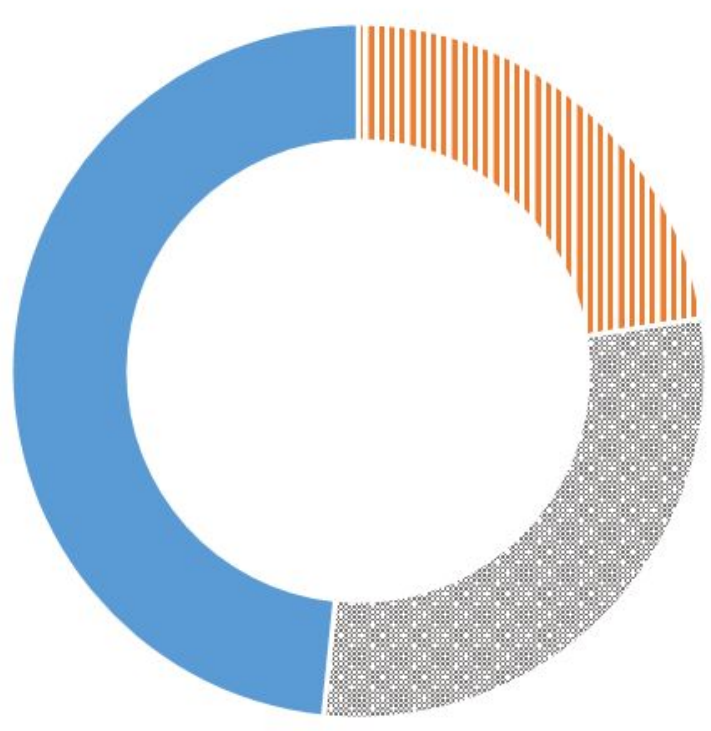

Figure 4. Proportion of studies according to the main digestive agent used.

Only a couple of studies have reported data on all types of anthropogenic particles, i.e., small pieces created or handled by humans, such as plastics, dyed particles or textile fibers. ${ }^{57,67}$ Indeed, studies have only focused on plastic materials and have developed protocols for that purpose. To our knowledge, few studies have tested the protocols used to extract MP from biota on natural or modified natural materials such as cellulose or cellulose acetate. ${ }^{58,68,69}$ Dehaut et al. ${ }^{58}$ tested three extraction protocols on cellulose acetate materials, in which two contained hydroxides $(\mathrm{NaOH} \& \mathrm{KOH})$ and one contained a combination of a hydroxide and an oxidizer $\left(\mathrm{NaOH} \& \mathrm{~K}_{2} \mathrm{~S}_{2} \mathrm{O}_{8}\right)$. All the protocols led to a mass reduction and a size and shape modification of the cellulose acetate while two of them allowed for identification by Raman spectroscopy. On the other hand, cellulose fibers, along with plastic polymers, were tested with an oxidizing agent and a combination of an oxidizer and an acid $\left(\mathrm{NaClO} \& \mathrm{HNO}_{3}\right) \cdot{ }^{68}$ Cellulose fibers were left unaffected by both treatments and Raman spectroscopy could successfully be performed. A potassium hydroxide-based protocol has also been tested on several natural materials. ${ }^{69}$ 
210 similar to the study by Dehaut et al. ${ }^{58}$ Some natural materials, such as sheep wool, were

211 dissolved, while others showed a resistance to KOH. The extraction method should then be

212

213

214

2.3. Extraction of MP: Filtration and targeted MP sizes

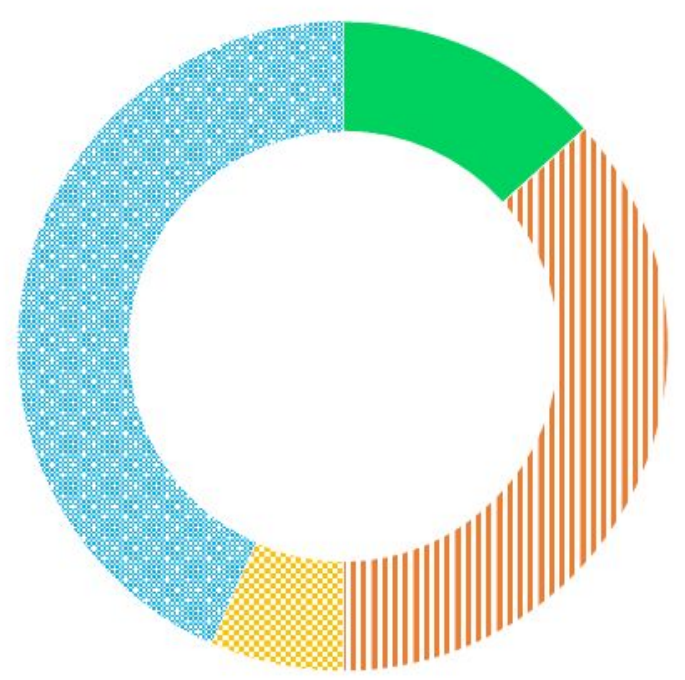

Figure 5. Proportion of studies according to their lowest limit of MP extracted. Based on Table 
227 The minimum size of the targeted particles is not always mentioned (Fig. 5). Generally, the particle isolation process includes a filtration/sieving step, in which a precise mesh size practically defines the threshold for particles to be further analyzed. In several studies, that mesh size is close to the micrometer scale (Fig. 5). Although this mesh size perfectly fits the microplastic size definition, from $5 \mathrm{~mm}$ down to a few microns, ${ }^{75}$ the limiting factor is then the spectroscopic analyses. Depending on the technique and equipment used, the size threshold allowing for the analysis of a particle varies. For instance, when dealing with particles between 1 and $20 \mu \mathrm{m}$ in length, Raman spectroscopy is recommended. ${ }^{76}$ However, if the aim of the study is to investigate direct ingestion by fish, it might not be worth studying such small MP. Adult fish are unlikely to ingest micron-sized particles because these particles will probably be ejected into the surrounding water from the branchial system, which is not adapted to retain such small particles. ${ }^{77}$ The filtration step could then be made easier by using larger mesh sizes depending on the studied species, mainly if no digestion step is performed. However, if the transfer of MP from prey is considered in the study, looking at smaller particles might be of interest. Regarding filtering fish, their filtration system defines the size limit of particles that are retained and further swallowed. For those species, correlating the filtration-limited size to the size of MP ingested might be a way to discriminate MP coming from prey (indirect ingestion) and MP ingested through feeding (direct ingestion). This assumption has to be assessed by future studies. A size of $5 \mu \mathrm{m}$ could be the lowest limit of investigated MP sizes, as it almost perfectly covers the MP size definition, which comprises direct and indirect MP ingestion and allows for reliable spectroscopic analyses. We encourage authors to provide at least the size classes of the ingested particles, as well as the size distribution. This information will allow for the comparison of those size classes according to the minimal size targeted and will provide baseline data for studies further dealing with the uptake of ingested MP by other organs and tissues. 
Half of the studies on plastics in freshwater fish used spectroscopic analyses to confirm the

255 plastic composition of the particles found, and most of these studies are the oldest (Table 1). When considering other matrices such as sediment or water, such techniques are often set aside. ${ }^{76}$ Thus, these techniques only rely on visual observation, which may bias the results. ${ }^{78-80}$ Visual observations with a stereomicroscope tend to underestimate the amount of microplastic fragments and, conversely, tend to overestimate the amount of MP fibers compared to the results obtained by Fourier transform infrared (FTIR) analyses. ${ }^{79}$ Markic et al. ${ }^{43}$ found that plastic was detected more often when a chemical digestion-coupled spectroscopic analyses was performed compared to visual methods alone. The smaller the particles are, the more difficult it is to distinguish them from biological tissues and to assess their synthetic composition with the naked eye. The 'hot point-test' is also sometimes used to determine the plastic composition of particles. ${ }^{18,81}$ This test consists of touching a particle with a hot needle and observing whether the needle leaves a mark on the particle. ${ }^{48,82}$ Although convenient and cheap, this technique should not be solely used for identification but used as a complement to visual sorting prior to spectroscopic analyses. ${ }^{48}$ In a report, the GESAMP group of experts ${ }^{40}$ stated that spectroscopy is recommended for particles smaller than $1 \mathrm{~mm}$. Consequently, using either Raman or FTIR spectroscopy when working with microplastic pollution is highly recommended. ${ }^{46,80}$ Both techniques usually allow for precisely identify the particle composition to be precisely identified and have the strong advantage of being nondestructive in contrast with other techniques such as pyrolysis-gas chromatography coupled with mass spectrometry (py-GC/MS) or thermogravimetric analysis coupled with solid-phase extraction (TGA-SPE). ${ }^{83-85}$ These techniques are complementary, as they give different information but using two or three of these techniques is obviously expensive and time-consuming. Therefore, depending on the 
277 information needed or the type of particle, researchers have to choose the best technique. Raman spectroscopy constitutes a better choice if results about additives are needed. Indeed Raman spectroscopy can provide additional information on dyes, for example, and will identify the composition of small particles $(<20 \mu \mathrm{m})$ that FTIR will miss. ${ }^{79,84,85}$ On the other hand, FTIR spectroscopy is less time-consuming and may allow for the identification of black particles that lead to fluorescence issues in Raman spectroscopy. ${ }^{84}$ All these techniques are expensive and time consuming; thus, a random subsample is often collected prior to the analyses, and the results are extrapolated to the total number particles found. ${ }^{10,44,86-88}$ This random subsample is usually poorly described and might result from subjective choices, especially regarding the sizes and colors. As selecting the particles may lead to bias, we instead recommend selecting a zone covering both the center and the edge of the filter (a half or a quarter) used during MP extraction.

Spectroscopic analyses provide useful and reliable data on particles. However, part of this data is often set aside because studies focus only on plastic polymers (Table 1). As explained in a previous section, we encourage researchers to provide all information, even on natural and semisynthetic materials.

\subsection{Expression of the results}

We recorded three different units of MP contamination in GCs, i.e., the percentage of contaminated individuals, the number of MP per individual and the number of MP in one gram of the GCs. Additionally, units of contamination differ between studies making comparisons impossible. All three units are easy to calculate and, although the most common (Table 2), the percentage of occurrence is not the most representative unit. This unit gives an overview of the number of fish having ingested at least one piece of plastic in a given time but does not give 
any valuable quantitative information. The number of MP per gram of GCs could be considered to be the most accurate unit but greatly depends on the fullness of the stomach or gut. As it is not clear whether MP have a greater retention time than food in the digestive tract, ${ }^{89,90}$ expressing the quantity of MP per mass of gut contents is not the most consistent option. It is instead preferable to express the results as the number of MP per individual and for comparison purposes, we recommend authors and researchers to report the results with the three units described in this review.

\subsection{Procedural blanks}

Procedural blanks (PBs), also termed controls or negative controls, ${ }^{47,91}$ are used in all procedure steps with the reagents only, and the sample in itself is excluded. Few studies that we have reviewed made PBs although most of the recent studies did. Even if contamination is prevented as best as possible, including PBs is recommended to evaluate possible contamination of the whole treatment protocol ${ }^{46,48}$ and, if needed, to adapt the results according to those blank data. ${ }^{18,82,91}$ Plastic contamination levels depend on many parameters, including the type of equipment used for sampling, the extraction and the analyses. ${ }^{92}$ Given that microplastic fibers are also found in the air, ${ }^{9,10}$ tap water ${ }^{93}$ and table salt, ${ }^{94,95}$ in which the latter is used in laboratories to perform density separation, PBs are necessary to evaluate the contamination levels in environmental samples. Moreover, we recommend including some PBs before starting the sample treatment. This will give an overview about the contamination level in the working environment, which can be then compared to the expected levels in the samples. This step could be critical if minimally contaminated samples are to be processed. In this case, PB levels would easily exceed what may be found in the samples, leading to an impossible interpretation of the results. Depending on the studies and equipment used, PB contamination can be important: 50 
327 times higher than plastics within the samples, ${ }^{96}$ or low: less than $5 \%$ of all plastics found in the 328 samples. ${ }^{44}$ However, if PB levels are assessed first, precautions and decisions can be made to 329 prevent the samples from being highly contaminated during the treatment. 
331 Table 1. Summary of studies reporting MP ingestion by wild freshwater fish and their methodologies.

\begin{tabular}{|c|c|c|c|c|c|c|c|c|c|c|c|c|c|c|c|}
\hline \multirow{2}{*}{$\begin{array}{l}\text { No. } \\
\text { sp. }\end{array}$} & \multirow[t]{2}{*}{$\mathrm{n} / \mathrm{sp}$} & \multirow[t]{2}{*}{ Country } & \multirow{2}{*}{$\begin{array}{l}\text { Water } \\
\text { body }\end{array}$} & \multicolumn{2}{|c|}{$\begin{array}{l}\text { Targeted } \\
\text { particles }\end{array}$} & \multirow{2}{*}{$\begin{array}{c}\text { Extracted } \\
\text { particle size } \\
(\mu \mathrm{m})\end{array}$} & \multirow{2}{*}{$\begin{array}{l}\text { Visual } \\
\text { sorting }\end{array}$} & \multicolumn{4}{|c|}{ Digesting agent } & \multicolumn{2}{|c|}{$\begin{array}{l}\text { Spectroscopi } \\
\text { c analyses }\end{array}$} & \multirow{2}{*}{$\begin{array}{l}\text { Procedural } \\
\text { blanks }\end{array}$} & \multirow[t]{2}{*}{ Reference } \\
\hline & & & & AP & $\mathrm{PL}$ & & & Hyd. & Acid & Enz. & Ox. & $\mathrm{Rn}$ & FTIR & & \\
\hline 3 & $\begin{array}{c}60,60 \\
62\end{array}$ & Brazil & $\mathrm{E}$ & - & $\mathrm{X}$ & $?$ & $\mathrm{X}$ & - & - & - & - & - & - & - & Possatto et al. ${ }^{97}$ \\
\hline 2 & $\begin{array}{c}239 \& \\
330\end{array}$ & Brazil & $\mathrm{E}$ & - & $X$ & $?$ & $\mathrm{X}$ & - & - & - & - & - & - & - & Dantas et al. ${ }^{49}$ \\
\hline 3 & $\begin{array}{c}240, \\
141,44\end{array}$ & Brazil & $\mathrm{E}$ & - & $\mathrm{X}$ & $?$ & $\mathrm{X}$ & - & - & - & - & - & - & - & Ramos et al. ${ }^{50}$ \\
\hline 1 & 186 & France & $\mathrm{R}$ & - & $\mathrm{X}$ & $>1.2$ & $\mathrm{X}$ & - & - & - & - & - & - & - & Sanchez et al. ${ }^{98}$ \\
\hline 2 & 20 & Tanzania & $\mathrm{L}$ & - & $\mathrm{X}$ & $>500$ & $\mathrm{X}$ & $\mathrm{X}$ & - & - & - & - & $\mathrm{X}$ & - & Biginagwa et al. ${ }^{99}$ \\
\hline 4 & 10 & Switzerland & $\mathrm{L}$ & - & $\mathrm{X}$ & $?$ & $\mathrm{X}$ & - & - & - & - & - & - & - & Faure et al. ${ }^{100}$ \\
\hline 44 & $1-67$ & U.S.A. & $\mathrm{R} \& \mathrm{E}$ & - & $\mathrm{X}$ & $?$ & $\mathrm{X}$ & - & - & - & - & - & $\mathrm{X}$ & - & Phillips \& Bonner ${ }^{101}$ \\
\hline 1 & 530 & Brazil & $\mathrm{E}$ & - & $\mathrm{X}$ & $?$ & $\mathrm{X}$ & - & - & - & - & - & - & - & Ferreira et al. ${ }^{102}$ \\
\hline 2 & $\begin{array}{c}318 \& \\
118\end{array}$ & U.S.A. & $\mathrm{R}$ & - & $\mathrm{X}$ & $>53$ & $\mathrm{X}$ & - & - & - & - & - & - & - & Peters \& Bratton ${ }^{103}$ \\
\hline 5 & $10-75$ & Canada & $\mathrm{R}$ & - & $\mathrm{X}$ & $>5$ & $\mathrm{X}^{*}$ & - & - & - & $\mathrm{X}$ & - & - & $\mathrm{X}$ & Campbell et al. ${ }^{96}$ \\
\hline 6 & $20-40$ & China & $\mathrm{L}$ & - & $\mathrm{X}$ & $>5$ & $\mathrm{X}$ & - & - & - & $\mathrm{X}$ & - & $\mathrm{X}$ & $\mathrm{X}$ & Jabeen et al. ${ }^{44}$ \\
\hline 2 & $10 \& 66$ & England & $\mathrm{R} \& \mathrm{E}$ & - & $\mathrm{X}$ & $?$ & $\mathrm{X}$ & - & - & - & - & - & $\mathrm{X}$ & - & McGoran et al. ${ }^{104}$ \\
\hline 11 & $1-21$ & Argentina & $\mathrm{E}$ & - & $\mathrm{X}$ & $?$ & $\mathrm{X}^{*}$ & - & - & - & $\mathrm{X}$ & - & - & - & Pazos et al..$^{56}$ \\
\hline 1 & 48 & Brazil & $\mathrm{R}$ & - & $\mathrm{X}$ & $>63$ & $\mathrm{X}$ & - & - & - & - & - & - & - & Silva-Cavalcanti et al. ${ }^{105}$ \\
\hline 27 & $2-215$ & Brazil & $\mathrm{E}$ & - & $\mathrm{X}$ & $?$ & $\mathrm{X}$ & - & - & - & - & - & - & - & Vendel et al. ${ }^{51}$ \\
\hline 13 & $1-6$ & China & $\mathrm{R}$ & - & $\mathrm{X}$ & $>1.2$ & $\mathrm{X}^{*}$ & $\mathrm{X}$ & - & - & - & $\mathrm{X}$ & - & - & Zhang et al..$^{59}$ \\
\hline 1 & 60 & France & $\mathrm{R}$ & $\mathrm{X}$ & $\mathrm{X}$ & $>5$ & - & - & - & - & $\mathrm{X}$ & $\mathrm{X}$ & - & $\mathrm{X}$ & Collard et al. ${ }^{57}$ \\
\hline 1 & 64 & England & $\mathrm{R}$ & $X$ & $X$ & $>1.2$ & $X$ & - & - & - & - & $X$ & - & - & Horton et al. ${ }^{67}$ \\
\hline 46 & $1-16$ & Brazil & $\mathrm{E}$ & - & $\mathrm{X}$ & $?$ & $\mathrm{X}$ & - & - & - & - & - & $\mathrm{X}$ & - & Pegado et al. ${ }^{52}$ \\
\hline 4 & $4-17$ & Iran & $\mathrm{E}$ & - & $\mathrm{X}$ & $?$ & $\mathrm{X}$ & $\mathrm{X}$ & $\mathrm{X}$ & - & $\mathrm{X}$ & - & - & $\mathrm{X}^{+}$ & Abbasi et al. ${ }^{106}$ \\
\hline 11 & $1-17$ & U.S.A. & $\mathrm{R}$ & - & $\mathrm{X}$ & $>0.45$ & $X^{*}$ & - & - & - & $\mathrm{X}$ & - & $\mathrm{X}$ & $\mathrm{X}$ & McNeish et al. ${ }^{91}$ \\
\hline 1 & 10 & China & $\mathrm{L}$ & - & $\mathrm{X}$ & $>200$ & $\mathrm{X}$ & $\mathrm{X}$ & - & - & - & $\mathrm{X}$ & - & $\mathrm{X}$ & Xiong et al. ${ }^{107}$ \\
\hline 16 & $1-63$ & Brazil & $\mathrm{R}$ & - & $\mathrm{X}$ & $?$ & $X$ & - & - & - & - & - & $\mathrm{X}$ & - & Andrade et al. ${ }^{108}$ \\
\hline 1 & 78 & Belgium & $\mathrm{R}$ & - & $\mathrm{X}$ & $>8$ & $X$ & - & - & - & $\mathrm{X}$ & $\mathrm{X}$ & $\mathrm{X}$ & $\mathrm{X}$ & Slootmaekers et al. ${ }^{109}$ \\
\hline 1 & 11 & China & $\mathrm{L}$ & - & $\mathrm{X}$ & $>8$ & $\mathrm{X}$ & $\mathrm{X}$ & - & - & $\mathrm{X}$ & $\mathrm{X}$ & - & $\mathrm{X}$ & Yuan et al. ${ }^{110}$ \\
\hline 14 & $8-9$ & China & $\mathrm{E}$ & - & $\mathrm{X}$ & $>20$ & $\mathrm{X}$ & - & - & - & $\mathrm{X}$ & - & $\mathrm{X}$ & $\mathrm{X}$ & Su et al. ${ }^{111}$ \\
\hline
\end{tabular}




\begin{tabular}{|c|c|c|c|c|c|c|c|c|c|c|c|c|c|c|c|}
\hline 2 & $\begin{array}{c}265 \& \\
184\end{array}$ & Brazil & $\mathrm{E}$ & - & $\mathrm{X}$ & $?$ & $\mathrm{X}$ & - & - & - & - & - & - & - & Ferreira et al. ${ }^{112}$ \\
\hline 1 & 20 & Argentina & $\mathrm{E}$ & - & $\mathrm{X}$ & $>8$ & $\mathrm{X}$ & - & - & - & $\mathrm{X}$ & - & - & - & Arias et al. ${ }^{113}$ \\
\hline 22 & - & Germany & $\mathrm{R} \& \mathrm{~L}$ & - & $\mathrm{X}$ & $>20$ & $\mathrm{X}$ & $\mathrm{X}$ & $\mathrm{X}$ & - & - & - & - & $\mathrm{X}$ & Roch et al. ${ }^{81}$ \\
\hline 1 & 180 & Australia & $\mathrm{W}$ & - & $\mathrm{X}$ & $>20$ & $\mathrm{X}$ & $\mathrm{X}$ & - & - & - & - & $\mathrm{X}$ & $\mathrm{X}$ & \multicolumn{2}{|c|}{ Su et al. ${ }^{114}$} \\
\hline
\end{tabular}

332 No.=number, $\mathrm{sp}=$ =species, $\mathrm{R}=$ river, $\mathrm{L}=$ =lake, $\mathrm{E}=$ estuary, $\mathrm{W}=$ =wetland, $\mathrm{FR}=$ fragments, $\mathrm{FI}=$ fibers, $\mathrm{AP}=$ anthropogenic particles excluding plastic particles,

$333 \mathrm{PL}=$ plastics, Hyd.=hydroxides, Enz.=enzymes, Ox.=oxidizers, Rn=Raman spectroscopy, FTIR=Fourier transform infrared spectroscopy.

$334 *$ Visual examination after the digestion process. In this table, when the minimum size of the MP was not mentioned in the study, the porosity of the

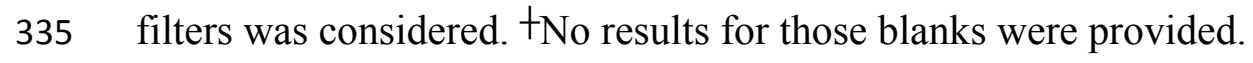


337 Table 2. Summary of plastic characteristics from gut contents of freshwater fish.

\begin{tabular}{|c|c|c|c|c|c|c|c|}
\hline \multirow[b]{2}{*}{ Species (n) } & \multirow[b]{2}{*}{ Location } & \multicolumn{3}{|c|}{ Plastic concentration or occurrence } & \multirow{2}{*}{$\begin{array}{l}\text { Mean plastic } \\
\text { size or range } \\
(\mathrm{mm})\end{array}$} & \multirow{2}{*}{$\begin{array}{l}\text { Spectroscopic } \\
\text { identification? }\end{array}$} & \multirow[b]{2}{*}{ Reference } \\
\hline & & Item/individual & Item/g GC & $\begin{array}{c}\text { Contaminated } \\
\text { individuals }(\%)\end{array}$ & & & \\
\hline Gobio gobio (78) & $\begin{array}{c}\text { Several rivers, } \\
\text { Belgium }\end{array}$ & - & - & 9 & 0.67 & Yes & 109 \\
\hline Gobio gobio (186) & $\begin{array}{l}\text { Several rivers, } \\
\text { France } \\
\end{array}$ & - & - & 12 & - & No & 98 \\
\hline Squalius cephalus & $\begin{array}{l}\text { Seine River, } \\
\text { France }\end{array}$ & $0.16^{*}$ & $0.16^{*}$ & 15 & $2.67 *$ & Yes & 57 \\
\hline 22 species & $\begin{array}{l}\text { Lakes \& rivers, } \\
\text { Germany }\end{array}$ & 0.2 & - & 18.8 & 0.889 & No & 81 \\
\hline $\begin{array}{c}\text { Alburnus alburnus } \\
\text { Perca fluviatilis } \\
\text { Rutilus rutilus (10) } \\
\text { Leuciscus leuciscus }\end{array}$ & $\begin{array}{l}\text { Lake Geneva, } \\
\text { Switzerland }\end{array}$ & $\begin{array}{c}3.1 \\
0 \\
0 \\
0.3 \\
\end{array}$ & - & 7.5 & - & No & 100 \\
\hline $\begin{array}{l}\text { Platichthys flesus } \\
\text { Osmerus eperlanus }\end{array}$ & $\begin{array}{l}\text { Thames Estuary, } \\
\text { England }\end{array}$ & - & - & $\begin{array}{l}85 \\
20\end{array}$ & - & Yes & 104 \\
\hline Rutilus rutilus (64) & $\begin{array}{l}\text { River Thames, } \\
\text { England }\end{array}$ & 0.69 & - & 32.8 & - & Yes & 67 \\
\hline $\begin{array}{c}\text { Platycephalus indicus } \\
\text { Saurida tumbil } \\
\text { Sillago sihama } \\
\text { Cynoglossus abbreviatus }\end{array}$ & $\begin{array}{l}\text { Musa Estuary, } \\
\text { Iran }\end{array}$ & $\begin{array}{l}2.3 \\
2.8 \\
1.5 \\
2.9\end{array}$ & - & - & - & No, SEM/EDS & 106 \\
\hline $\begin{array}{c}\text { Lates niloticus } \\
\text { Oreochromis niloticus }\end{array}$ & $\begin{array}{c}\text { Lake Victoria, } \\
\text { Tanzania } \\
\end{array}$ & - & - & $\begin{array}{l}20 \\
20 \\
\end{array}$ & - & Yes & 99 \\
\hline $\begin{array}{c}\text { Lepomis macrochirus (318) } \\
\text { Lepomis megalotis (118) }\end{array}$ & $\begin{array}{l}\text { Brazos River, } \\
\text { Texas, U.S.A. }\end{array}$ & - & - & 45 & - & No & 103 \\
\hline 44 species & $\begin{array}{l}\text { Several rivers, } \\
\text { Texas, U.S.A. }\end{array}$ & - & - & 8.2 & - & Yes & 101 \\
\hline 17 species & $\begin{array}{l}\text { Several rivers, } \\
\text { U.S.A. }\end{array}$ & $\sim 13$ & - & 85 & $<1.5$ & Yes & 91 \\
\hline $\begin{array}{c}\text { Esox lucius } \\
\text { Catostomus commersoni } \\
\text { Notropis atheirnoides } \\
\text { Pimephales promelas (34) }\end{array}$ & $\begin{array}{l}\text { Wascana Creek, } \\
\text { Canada }\end{array}$ & - & - & 73.5 & - & No & 96 \\
\hline
\end{tabular}




\begin{tabular}{|c|c|c|c|c|c|c|c|}
\hline Eucalia inconstans & & & & & & & \\
\hline 11 species & $\begin{array}{c}\text { Rio de La Plata, } \\
\text { Argentina }\end{array}$ & 19.2 & - & 100 & $0.06-4.7$ & No & 56 \\
\hline Micropogonias furnieri & $\begin{array}{c}\text { Bahía Blanca } \\
\text { Estuary, } \\
\text { Argentina }\end{array}$ & 12.1 & - & - & 2.4 (median) & No & 113 \\
\hline 16 species & $\begin{array}{c}\text { Xingu River, } \\
\text { Brazil }\end{array}$ & - & - & 26.7 & $1-15$ & Yes & 108 \\
\hline 46 species & $\begin{array}{c}\text { Amazon Estuary, } \\
\text { Brazil }\end{array}$ & 1.2 & - & 13.7 & 1.82 & Yes & 52 \\
\hline Hoplosternum littorale & $\begin{array}{c}\text { Pajeú River, } \\
\text { Brazil }\end{array}$ & 3.6 & - & 83 & $<1-12$ & No & 105 \\
\hline 69 species & $\begin{array}{c}\text { Paraiba Estuary } \\
\text { Mamanguape } \\
\text { Estuary, Brazil }\end{array}$ & $\begin{array}{l}0.07 \\
0.12\end{array}$ & - & 9 & - & No & 52 \\
\hline $\begin{array}{c}\text { Cathorops spixii } \\
\text { Cathorops agassizii } \\
\text { Sciades herzbergii } \\
\end{array}$ & $\begin{array}{c}\text { Goiana Estuary, } \\
\text { Brazil }\end{array}$ & - & - & $\begin{array}{l}18 \\
33 \\
17 \\
\end{array}$ & - & No & 97 \\
\hline $\begin{array}{c}\text { Stellifer brasiliensis (330) } \\
\text { Stellifer stellifer }\end{array}$ & $\begin{array}{c}\text { Goiana Estuary, } \\
\text { Brazil }\end{array}$ & - & - & $\begin{array}{l}6.9 \\
9.2 \\
\end{array}$ & - & No & 49 \\
\hline $\begin{array}{l}\text { Eugerres brasilianus (240) } \\
\text { Eucinostomus melanopterus } \\
\text { Diapterus rhombeus (44) }\end{array}$ & $\begin{array}{c}\text { Goiana Estuary, } \\
\text { Brazil }\end{array}$ & - & - & $\begin{array}{c}16.2 \\
9.2 \\
11.4\end{array}$ & $1-5$ & No & 50 \\
\hline Cynoscion acoupa & $\begin{array}{c}\text { Goiana Estuary, } \\
\text { Brazil }\end{array}$ & - & - & 64.2 & $<5$ & No & 102 \\
\hline $\begin{array}{l}\text { Centropomus undecimalis } \\
\text { Centropomus mexicanus }\end{array}$ & $\begin{array}{c}\text { Goiana Estuary, } \\
\text { Brazil }\end{array}$ & $\begin{array}{l}1.5 \\
1.4 \\
\end{array}$ & - & - & $\sim 1.25$ & No & 112 \\
\hline 6 species & $\begin{array}{c}\text { Taihu Lake, } \\
\text { China }\end{array}$ & 2.4 & 3.4 & 95.7 & $0.4-24.8$ & Yes & 44 \\
\hline 14 species & $\begin{array}{l}\text { Yangtze Estuary } \\
\text { Hangzhou Bay, } \\
\text { China }\end{array}$ & $\begin{array}{l}0.3-4.5 \\
0.5-5.3\end{array}$ & $\begin{array}{l}0.3-6.2 \\
0.1-8.8\end{array}$ & - & $\begin{array}{l}22-100 \\
25-100\end{array}$ & Yes & 111 \\
\hline 13 species & $\begin{array}{c}\text { Xiangxi River, } \\
\text { China }\end{array}$ & - & - & 25.7 & $0.3-1.8$ & Yes & 59 \\
\hline Gymnocypris przewalskii & $\begin{array}{c}\text { Qinghai Lake, } \\
\text { China }\end{array}$ & 5.4 & - & - & - & Yes & 107 \\
\hline
\end{tabular}




\begin{tabular}{|c|c|c|c|c|c|c|c|}
\hline Carassius auratus (11) & $\begin{array}{c}\text { Poyang Lake, } \\
\text { China }\end{array}$ & - & - & 91 & $0.1-1$ & Yes \\
\hline Gambusia holbrooki & $\begin{array}{c}\text { Melbourne Area, } \\
\text { Australia }\end{array}$ & 0.60 & - & 110.4 & $0.09-4.86$ & Yes \\
\hline
\end{tabular}

$\mathrm{GC}=$ gut contents. The bolded items are the species studied in at least two publications with the number of individuals sampled. *Personal unpublished

339 data and the data published Collard et al. ${ }^{57}$, which concerned all anthropogenic particles. When the global mean is not provided, we gave the total range. 
3. Factors influencing MP ingestion by freshwater fish

Here, we aimed to discuss factors that are likely to influence MP ingestion by freshwater fish foraging for prey. Those factors include specific traits, such as the feeding strategy, and abiotic parameters, such as the environmental MP levels. However, the results in the discussed in situ studies are also influenced by the retention time of MP inside the gut, which is not well understood. The results might be different depending on the size of plastic pieces or the species. Also, the gut content reflects only the instantaneous diet, that is why repeated studies should be performed.

\subsection{Levels in abiotic compartments}

According to studies, several factors are at play when plastic is ingested by fish. The first factor to consider is probably the exposure. Very few studies have investigated both the abiotic contamination and MP ingestion by freshwater fish. Therefore, this section will give an overview of the contamination levels in those matrices as a first step in determining what induces or prevents MP ingestion.

Many different units are used for both water and sediment concentrations (Table S1), which is also the case for marine environments. ${ }^{115,116}$ Regarding water contamination, the results are often given in items per cubic meter of water, and the format "items/volume" is the most commonly used. Regarding the sediment, the results are usually expressed in items per kilogram of sediment (dry weight).

Remarkably, all except one study chose to express their results per dry weight. We thus encourage researchers to further express sediment concentration per dry weight too. In addition, some authors calculated the mean concentration while others chose to only show a range. Some authors also excluded values equal to zero from the mean calculation, and others did not give any concentration mean or range. While a global mean value may be very restrictive and not representative of all the parameters such as the different rivers sampled or difference in the sampling locations (close or far 
from an outlet, close or far from urban activities, etc.), we recommend showing as many values as possible. This will allow further studies to choose the most convenient and adapted value to be compared to.

When considering studies that performed analyses in both water and sediment samples obtained from the same place, several trends and questions arise. Regarding the abundances of MP, some studies found different patterns for the two compartments..$^{59,110,117,118}$ The authors of these studies discussed those results by mentioning potential factors that could influence MP distribution. MP levels in lake sediments are related to their distance from MP sources. ${ }^{19,120}$ Yuan et al. ${ }^{110}$ confirmed this fact. The northern and middle regions of Poyang Lake are subject to anthropogenic activities and are the most contaminated parts with regards to the sediment and surface waters, respectively. Sediment and water obtained from the south of Poyang Lake, where less human activities occur, are less contaminated than those of the northern and middle regions. Furthermore, the presence of a wastewater treatment plant in the vicinity of a sampling station might induce higher concentrations of polyethylene terephthalate (PET) fibers. ${ }^{117,121}$

The topography of the environment may also be a factor of the concentration or dilution of MP in sediment. ${ }^{122}$ In addition, the hydrodynamics, which are influenced by the shoreline morphology, may favor or prevent the deposition of plastics in the sediment; a low velocity environment, such as a harbor will enable plastics to settle..$^{59,97,120,123}$

Surprisingly, MP contamination in fish shows different patterns than MP contamination in water or sediment for at least one characteristic (Table S2). Sometimes, a correlation between the water or sediment contamination and fish contamination exists for only one or two parameter(s) (e.g., the shape or the size range) or at one sampling location. ${ }^{91}$ Therefore, this shows evidences that exposure is not the only factor involved, ${ }^{67}$ and perhaps, that exposure is not a factor at all. ${ }^{124}$ Of course, MP ingestion cannot occur if there is not any plastic in the environment, but Kim et al. ${ }^{124}$ found that the food concentration is surprisingly more important than the MP concentration in influencing MP ingestion. Kim et al. ${ }^{124}$ exposed zebrafish to various mixtures of MP and food and concluded that MP 
392 ingestion increased with increasing concentrations of food. However, in that study, the authors 393 exposed fish to virgin plastic. It is now known that animals react differently to virgin or biofouled 394 plastic. The copepods Calanus finmarchicus and female copepods Acartia longiremis ingested 395 significantly more biofouled PS beads than virgin PS beads. ${ }^{125}$ Similarly, procellariiform seabirds can 396 be fooled by the dimethyl sulfide signature present on marine plastic particles. ${ }^{126}$ In 2017 , it has also 397 been shown that Engraulis mordax anchovies responded to medium and high concentrations of 398 biofouled plastic odors with foraging behaviors. ${ }^{127}$ Those behaviors did not appear when these 399 anchovies were exposed to clean plastic particles.

400 Indirectly, surface runoff and seasons also indirectly act on the exposure level. ${ }^{112,128}$ Surface runoff 401 increases the exposure to plastic debris. ${ }^{112}$ Consequently, the exposure plays a role, but the ingestion 402 also depends on other parameters, such as the age of the plastic particle or the time of the year.

403

404 405 406 407 408 409 410

3.2. Living habitat

Sediment is a sink for microplastics, ${ }^{4,129}$ and therefore, demersal and benthic fish could be exposed to more MP than pelagic species. Some studies have focused on both pelagic and benthic or demersal fish with varying results. In China, demersal species ingested more plastics than pelagic species. ${ }^{44}$ The same assumption was made by McGoran et al. ${ }^{104}$; a demersal species, Platichthys flesus flounder had ingested far more MP than a pelagic species, Osmerus eperlanus smelt. McGoran et al. ${ }^{104}$ assumed that $P$. flesus had ingested more MP, because it ingested sediment, likely leading to the unintended ingestion of MP. In the marine Scottish waters, demersal fish species have ingested more plastics than pelagic species. ${ }^{45}$ They also found a significant difference between coastal and offshore species, in which the former are more contaminated than the latter. Nevertheless, this latter category was only represented by demersal species, which may lead to the wrong conclusions about the involvement of the fish species coastal habitat on MP ingestion. Not all studies focusing on MP ingestion by pelagic and demersal fish found a difference between these two categories. ${ }^{130}$ Moreover, 
Rummel et al. ${ }^{22}$ showed that pelagic feeders had more MP in their stomach than demersal fish. Again, as methods vary from one study to another and as MP ingestion depends on several factors, the results may vary when looking at only one factor.

A more commonly discussed parameter is the feeding strategy of fish and their trophic position. It is thought that (top-)predator fish from both fresh and marine environments might be more at risk than organisms at lower trophic levels because of high energy requirements and trophic transfer. ${ }^{91,96,102,112,131}$ Other predators such as marine mammals have ingested MP that are too small to be preyed upon by such larger animals. ${ }^{13,132,133}$ This suggests that secondary ingestion has occurred and thus, MP have accumulated through the food chain. The developmental stage of fish might also influence MP ingestion. ${ }^{67}$ Indeed, many fish change their diet throughout their development. ${ }^{134-137}$ Ferreira et al. ${ }^{102}$ studied MP contamination in several ontogenetic phases of Cynoscion acoupa. The adults, which are mainly piscivorous, were more contaminated than juveniles and subadults, which exhibit an omnivorous diet. This result leads to the same conclusion previously reported: predator or piscivorous fish are more at risk than fish displaying another type of feeding strategy. Later, Ferreira et al. ${ }^{12}$ made the same conclusion for two other species (the snook Centropomus undecimalis and Centropomus mexicanus) obtained from the same location, the Goiana Estuary. Three ontogenetic phases were sampled and compared. Juvenile snook registered the lowest MP ingestion level while the piscivorous adults, registered the highest. Moreover, peaks of MP ingestion by adults coincide with peak of fish ingestion. Other studies did not find such differences, ${ }^{108}$ indicating the possibility for other parameters to be involved. For example, in the marine environment, debris categories were related to the feeding behavior of the sampled fish. ${ }^{138}$ Opportunistic feeders ingested all debris categories (i.e., metals, wood, and plastics), while pelagic feeders had only swallowed plastic bags, benthic fish, and hard plastic pieces. 
Based on the fish feeding habits, the visual characteristics of plastic pieces may be involved in MP ingestion by particulate-feeders. In contrast to ram-feeding, which consists of passively filtering water and is nonselective, particulate-feeding is a selective mode, where prey are visually detected before their capture. ${ }^{139}$ Then, ram-feeders are less likely to be influenced by the visual characteristics of plastics. ${ }^{77}$ Yuan et al. ${ }^{110}$ noticed that white MP were more frequently found in fish stomachs than in both water and sediment. Yuan et al. ${ }^{110}$ supposed that Carassius auratus could mistake MP for planktonic food. Ory et al. ${ }^{140}$ studied Seriolella violacea juveniles in controlled conditions and exposed them to food-shaped and food-sized polyamide particles with different colors. As expected, the juveniles preferentially ingested black particles, which is the same color as food pellets. The other colored particles were supposed to be cocaptured with the food, as they were ingested together with the food pellets only. Nevertheless, attention should be paid to the digesting agent used in the extraction process as some agents, such as $\mathrm{NaClO}$, change or discolor the particles. ${ }^{68}$ In a more global framework, the likelihood that beached macroplastics were previously bitten by fish and other organisms depends on the plastic colors. ${ }^{141}$ Blue and yellow macroplastics were preferentially more than were other colors. Similarly, plastic threads were the main plastic type ingested by Cynoscion acoupa in the Goiana Estuary, while plastic threads represented only $1.4 \%$ of all the plastic debris in the water column. ${ }^{102,142}$ Several colors of threads were ingested, suggesting that the plastic shape was more important than the color for this species. The same observation was made by Carson, ${ }^{141}$ who found that bottle shaped macroplastics displayed more bite marks than other shapes. Visual and chemical cues thus interfere together with the feeding behavior of fish, making the understanding of MP ingestion in fish even more challenging. Further studies that will consider several parameters are needed to understand the different pathways involved. Increasing the knowledge of those factors will help to suggest and define species for the monitoring of plastic pollution in both fresh and marine waters.

4. Freshwater fish for the biomonitoring of MP contamination? 
471 The occurrence of a contaminant in an ecosystem does not mean that the contaminant will cause harm

to the populations inhabiting the ecosystem. Biota is needed to link the pollutant levels in abiotic compartments and in organisms' tissue to potential adverse effects. ${ }^{143}$ Using fish species for the assessment of the quality of aquatic ecosystems is highly relevant. Fish are found everywhere in aquatic environments and have an intermediate trophic position, linking the lower trophic positions to the higher trophic positions (Beyer 1996 in van der Oost et al. ${ }^{143}$ ). Nevertheless, attention must be paid when choosing a species for monitoring. The GESAMP ${ }^{46}$ report suggested a list of criteria that helps to define good species for monitoring. This species, or group of species, must be representative of different life histories, phylogenies, sizes, ages and developmental stages. General strategies are proposed, which include opportunistic sampling, market sampling of commercial species and targeting biota. In this report, it is stated that fish, as targeted species or those purchased from the markets, could constitute a good monitoring group for the ingestion of MP. ${ }^{46}$

Given the numerous factors influencing the ingestion of MP by fish, choosing only one indicator species or a group of species is challenging and perhaps impossible. The ecology and feeding habits of the chosen species must be known. It is important to know where the fish, as well as all its developmental stages, is located within the food web, for instance. Here, we present a summary of the parameters to be considered when choosing an indicator fish species, for both fresh and marine environments:

- Trophic position. As discussed in the previous section, predators, especially top-predators, are more likely to ingest MP through food transfer. However, monitoring MP pollution with toppredators will not accurately indicate the contamination level of the environment (water and sediment) but will give global information on the trophic web and the ecosystem.

- Feeding strategy. Ram-feeding fish passively filter water without any visual search for food. They may be good indicators of the MP levels in the surrounding water. In this case, in addition to gut contents, we advise researchers to also examine the gill rakers, which are bony 
In summary, the perfect fish species used to monitor MP pollution in fresh and marine water is either

or cartilaginous structures attached to the branchial arches that retain filtered particles inside the mouth. Those analyses will complete the GC results.

- Migrations. Many fish migrate, either vertically (diel migrations) or horizontally (seasonal migrations), and sometimes fish migrate both ways. Depending on the area chosen to be studied, all types of migration can be valuable. Diel migrations could inform researchers about the MP levels in the pelagic zone, as the surface, seasonal and spatial migrations could provide data for the same species but in different areas. Utilizing the same species is important, as it avoids some bias caused by specific related factors, such as the fish length, the mouth structure and the fish vision. Whatever the chosen species and area, the sampling protocol must be designed considering those migration types. Fish must be sampled at the same time of the day or year if only one location or one water column compartment is targeted.

- Commercial value. Collecting commercially valued fish is advantageous as this is a costeffective method for the assessment of human exposure through the chosen species. ${ }^{46}$ Indeed, commercial fish can be purchased at markets, which eliminates evident sampling costs. However, it may not be possible to obtain precise information regarding the sampling location.

- Living habitat. Benthic and demersal species will provide information about a sea compartment that is different than the sea compartment of pelagic species. Demersal fish will give a less accurate overview of the benthic compartment than benthic fish, as demersal fish are not fully associated with the sediment.

- Distribution. For comparison and repeatability purposes, the chosen species should have the widest distribution possible or should at least belong to a higher taxon (genus or family) that is distributed worldwide distributed in order to avoid biases linked to the different species used in various studies. 
522

species is restricted to a small area, similar species must be found in other areas of the world. The migration of the selected fish must be well known and considered when sampling. Researchers must then carefully choose the correct species according to the information they need.

5. Perspectives and recommendations

To provide perspectives for further research, we want to highlight three steps of protocols that are of great importance: the number of samples analyzed, the size limit of the extracted particles and their identification.

Sample sizes vary greatly between studies, as sizes vary from 1 to 330 individuals for a single species. A sample size of 50 individuals has been determined to be sufficient for plastic pollution research. ${ }^{53}$ A couple of samples is not useful for research; in addition to being statistically irrelevant, time and/or money can be saved by not sampling such small sample sizes and perhaps used for better purposes. Achieving 50 individuals per studied criterion can be challenging, and therefore, we recommend sampling as close to 50 individuals as possible by sampling the same species from a specific location, for example.

Studies have rarely identified the target size range of MP extracted from fish gut contents (Table 2). The only information available is the mesh size of the filters used during the extraction step when present. Usually, that mesh size is approximately a micrometer, which allows researchers to extract very small particles, but such particles are hardly observed visually and analyzed spectroscopically. In contrast, focusing on large MP might lead to an underestimation of the number of ingested particles. Both large and small fish are likely to ingest small MP $(<100 \mu \mathrm{m})$ either by transfer from prey to predator or through their feeding behavior. It is thus critical to specify which threshold is applied in each study to promote comparability. This threshold must be defined according to the identification method used; FTIR and Raman spectroscopies allow researchers to analyze MP that are smaller than the particles visible by visual observation through a stereomicroscope. 
MP have often been identified by visual inspection, although the identification techniques used have seemingly improved in recent studies. Only two studies on MP contamination in freshwater fish included all dyed particles, even if the particles were not made of plastic (Table 1). We believe that it is important to report all types of anthropogenic contamination in fish tissues, especially textile fibers, which are usually dyed and released in large amounts into the environment. ${ }^{144,145}$

With regards to contamination, we suggest that (1) sample collection is performed with as few plastic materials as possible, (2) all solutions, including tap water, must be filtered with filters having the same porosity as the one used to filter the samples and stored in glass jars, (3) plastic materials should be avoided during sample treatment, (4) if the laboratory work cannot be performed in a clean room, the laboratory should then be ventilated as much as possible, (5) all equipment must be covered with clean non-plastic materials when not in use and (6) the laboratory operator should wear nonsynthetic clothes, a cotton lab coat and gloves. Avoiding plastic during the sampling and treatment steps is not easy, especially regarding the textiles worn, solution storage and use of nonsynthetic gloves, but for the latter at least, an FTIR or Raman spectrum can be recorded and matched with the potential contaminating particles found in the samples. If contamination does occur, those particles can then be excluded from the results.

As previously recommended by published reviews, ${ }^{40,47,48}$ standardized protocols are required. Thus we briefly recommend an overall optimal methodology that can be used when evaluating MP pollution by working with fish gut samples: (1) the number of sampled individuals should be as close to 50 as possible, (2) a MP target size down to $1 \mu \mathrm{m}$ should be considered to fit the MP definition, (3) enzymes should be used as digesting agents, (4) identification should be performed by spectroscopy, (5) qualitative observations should be made by light microscopy, (6) as many data as possible (averages and ranges, global contamination or per category, etc.) should be provided, (7) the results should be expressed using several units and per category studied (feeding strategy, developmental stage, etc.), and (8) procedural blank samples should be prepared and analyzed. Spectroscopic analyses can be performed on a subsample of the total amount of extracted particles. 
However, when focusing on fish contamination, it is uncommon to find tens of particles in a single individual. Therefore, we recommend analyzing all particles extracted from the fish GCs. Visual observations are not recommended for sorting or identifying microplastics but are required to take pictures and to measure the MP found. We encourage researchers to keep that step only for those purposes. The global evaluation of the protocol quality can be made thanks to the quality assessment system proposed by Hermsen et al. ${ }^{48}$ This quality assessment has been adapted for MP ingestion from the CRED scoring system ${ }^{146}$ and provides a good overview of the protocol strength.

This review examines MP in the digestive tracts of freshwater fish, but MP appear to translocate to other organs in several aquatic taxonomic groups, including freshwater fish. ${ }^{57,61,111,147-149}$ The impacts of MP translocation are not well known, and MP pathways still need to be understood. The liver has primarily been studied, but other tissues are worth investigating. Based on the human health perspective, muscle is obviously the first tissue that comes to mind, as muscle is almost the only part of the fish we consume. Few studies have examined MP in fish muscle, ${ }^{57,106,111,147}$ and when MP are found in the muscle, their pathways are unknown. In this regard, in vitro studies using biofouled plastics are needed to provide more information about the translocation process(es).

Selecting one or more species suitable for monitoring is currently challenging. First, studies must be performed on MP ingestion by fish and MP contamination in their nearby environment. Studies should be performed at the same time and, of course, by utilizing proper methods with chemical treatment and identification. This will allow scientists to determine which species reflects the best environmental contamination and thus to decide which species can be defined as an indicator. Furthermore, assessing the species monitoring process is only the first step towards obtaining a more global understanding of MP pollution in biota. To date, most studies on MP ingestion by fish are quite descriptive and contain suggested explanations that are usually not demonstrated, and potential impacts are listed. The quantity and quality of research require improvements to be made to assess the ecological risk posed by MP. ${ }^{150}$ A description of the contamination levels is obviously of great 
600 importance to the scientific community, but we think that only studying MP contamination is not 601 sufficient. Microplastics alone have been found to negatively impact fish, ${ }^{25,151,152}$ but MPs are part of 602 a cocktail of pollutants containing additives, e.g., phthalates and bisphenols, dyes, organic pollutants, 603 among others. These pollutants are also known to affect fish in several ways. ${ }^{153-155}$ Consequently, MP 604 should be monitored concomitantly with other pollutants to more accurately reflect the ecological 605 state of freshwaters with regards to pollution.

606

607 In conclusion, this review aims to highlight the need for the standardization of methodologies and to 608 give an overview of the factors involved in the ingestion of MP by freshwater fish. The first step of 609 standardization can be to follow several recommendations, such as suggesting that a sufficient 610 number of individuals be sampled and recommending the systematic use of spectroscopy to identify 611 polymer particles. With regards to biomonitoring, studies should be performed using the same overall 612 methodology and the same or very similar fish species. These species must be chosen for the purpose 613 of monitoring and based on their biological characteristics: top-predator and ram-filtering species 614 provide useful information with regards to plastic contamination.

The Supporting Information is available free of charge on the ACS Publications website at DOI: $619 \mathrm{XXX}$

An overview of the studies reporting plastic contamination in freshwaters and a summary of data regarding MP contamination in abiotic compartments and fish at the same location. 
625 This work has been performed at both the University of Paris-Est Créteil (UPEC) and Norwegian 626 Polar Institute. While working at the UPEC, F. Collard received funding from the People Programme 627 (Marie Curie Actions) of the European Union Seventh Framework Programme (FP7/2007-2013) 628 under the REA grant agreement n. PCOFUND-GA-2013-609102 and through the PRESTIGE 629 Programme coordinated by Campus France (postdoctoral grant). 630 
631 8. References

632

633 (1) Ryan, P. G. A Brief History of Marine Litter Research. In: Marine Anthropogenic Litter; Bergmann,

(3) Gago, J.; Carretero, O.; Filgueiras, A. V.; Viñas, L. Synthetic Microfibers in the Marine

(5) Tekman, M. B.; Krumpen, T.; Bergmann, M. Marine Litter on Deep Arctic Seafloor Continues to

(6) Obbard, R. W.; Sadri, S.; Wong, Y. Q.; Khitun, A. A.; Baker, I.; Thompson, R. C. Global Warming

(7) Peeken, I.; Primpke, S.; Beyer, B.; Gütermann, J.; Katlein, C.; Krumpen, T.; Bergmann, M.;

Hehemann, L.; Gerdts, G. Arctic Sea Ice Is an Important Temporal Sink and Means of Transport for Microplastic. Nat. Commun. 2018, 9 (1), 1505. https://doi.org/10.1038/s41467-018-03825-5.

(8) Liu, M.; Lu, S.; Song, Y.; Lei, L.; Hu, J.; Lv, W.; Zhou, W.; Cao, C.; Shi, H.; Yang, X.; et al. Microplastic and Mesoplastic Pollution in Farmland Soils in Suburbs of Shanghai, China. Environ. Pollut. 2018, 242, 855-862. https://doi.org/10.1016/j.envpol.2018.07.051.

9) Dris, R.; Gasperi, J.; Saad, M.; Mirande, C.; Tassin, B. Synthetic Fibers in Atmospheric Fallout: A Source of Microplastics in the Environment? Mar. Pollut. Bull. 2016, 104 (1-2), 290-293. 
https://doi.org/10.1016/j.marpolbul.2016.01.006.

(10) Cai, L.; Wang, J.; Peng, J.; Tan, Z.; Zhan, Z.; Tan, X.; Chen, Q. Characteristic of Microplastics in the Atmospheric Fallout from Dongguan City, China: Preliminary Research and First Evidence. Environ. Sci. Pollut. Res. 2017, 24 (32), 24928-24935. https://doi.org/10.1007/s11356-017-0116-x.

(11) Marine Anthropogenic Litter; Bergmann, M., Gutow, L., Klages, M., Eds.; Springer International Publishing: Cham, 2015. https://doi.org/10.1007/978-3-319-16510-3.

(12) Lusher, A. L.; Hernandez-Milian, G.; O’Brien, J.; Berrow, S.; O’Connor, I.; Officer, R. Microplastic and Macroplastic Ingestion by a Deep Diving, Oceanic Cetacean: The True's Beaked Whale Mesoplodon Mirus. Environ. Pollut. 2015, 199, 185-191.

(13) Nelms, S. E.; Galloway, T. S.; Godley, B. J.; Jarvis, D. S.; Lindeque, P. K. Investigating Microplastic Trophic Transfer in Marine Top Predators. Environ. Pollut. 2018, 238, 999-1007. https://doi.org/10.1016/J.ENVPOL.2018.02.016.

(14) Zhu, J.; Yu, X.; Zhang, Q.; Li, Y.; Tan, S.; Li, D.; Yang, Z.; Wang, J. Cetaceans and Microplastics: First Report of Microplastic Ingestion by a Coastal Delphinid, Sousa Chinensis. Sci. Total Environ. 2019, 659, 649-654. https://doi.org/10.1016/j.scitotenv.2018.12.389.

(15) Trevail, A. M.; Gabrielsen, G. W.; Kühn, S.; Van Franeker, J. A. Elevated Levels of Ingested Plastic in a High Arctic Seabird, the Northern Fulmar (Fulmarus Glacialis). Polar Biol. 2015, 38 (7), 975981. https://doi.org/10.1007/s00300-015-1657-4.

(16) Zhao, S.; Zhu, L.; Li, D. Microscopic Anthropogenic Litter in Terrestrial Birds from Shanghai, China: Not Only Plastics but Also Natural Fibers. Sci. Total Environ. 2016, 550, 1110-1115. https://doi.org/10.1016/j.scitotenv.2016.01.112.

(17) Reynolds, C.; Ryan, P. G. Micro-Plastic Ingestion by Waterbirds from Contaminated Wetlands in South Africa. Mar. Pollut. Bull. 2018, 126, 330-333. https://doi.org/10.1016/J.MARPOLBUL.2017.11.021.

(18) Devriese, L. I.; van der Meulen, M. D.; Maes, T.; Bekaert, K.; Paul-Pont, I.; Frère, L.; Robbens, J.; Vethaak, A. D. Microplastic Contamination in Brown Shrimp (Crangon Crangon, Linnaeus 1758) from Coastal Waters of the Southern North Sea and Channel Area. Mar. Pollut. Bull. 2015, 98 (1), 179-187. https://doi.org/10.1016/j.marpolbul.2015.06.051.

(19) Iannilli, V.; Di Gennaro, A.; Lecce, F.; Sighicelli, M.; Falconieri, M.; Pietrelli, L.; Poeta, G.; Battisti, 
C. Microplastics in Talitrus Saltator (Crustacea, Amphipoda): New Evidence of Ingestion from Natural Contexts. Environ. Sci. Pollut. Res. 2018, 25 (28), 28725-28729.

https://doi.org/10.1007/s11356-018-2932-z.

(20) Hurley, R. R.; Woodward, J. C.; Rothwell, J. J. Ingestion of Microplastics by Freshwater Tubifex Worms. Environ. Sci. Technol. 2017, 51 (21), 12844-12851. https://doi.org/10.1021/acs.est.7b03567.

(21) Bråte, I. L. N.; Eidsvoll, D. P.; Steindal, C. C.; Thomas, K. V. Plastic Ingestion by Atlantic Cod ( Gadus Morhua ) from the Norwegian Coast. Mar. Pollut. Bull. 2016, 112 (1-2), 105-110. https://doi.org/10.1016/j.marpolbul.2016.08.034.

(22) Rummel, C. D.; Löder, M. G. J.; Fricke, N. F.; Lang, T.; Griebeler, E.-M.; Janke, M.; Gerdts, G. Plastic Ingestion by Pelagic and Demersal Fish from the North Sea and Baltic Sea. Mar. Pollut. Bull. 2016, 102 (1), 134-141. https://doi.org/10.1016/j.marpolbul.2015.11.043.

(23) Collicutt, B.; Juanes, F.; Dudas, S. E. Microplastics in Juvenile Chinook Salmon and Their Nearshore Environments on the East Coast of Vancouver Island. Environ. Pollut. 2019, 244, 135-142. https://doi.org/10.1016/j.envpol.2018.09.137.

(24) Arthur, C.; Baker, J.; Bamford, H. Proceedings of the International Research Workshop on the Occurrence, Effects and Fate of Microplastic Marine Debris. In Proceedings of the International Research Workshop on the Occurrence, Effects and Fate of Microplastic Marine Debris.; Technical Memorandum NOS-OR\&R-30; Proceedings of the International Research Workshop on the Occurrence, Effects, and Fate of Microplastic Marine Debris Courtney Arthur, Joel Baker, and Holly Bamford (eds.) National Oceanic and Atmospheric Administration: University of Washington Tacoma campus in Tacoma, Washington, USA, 2008.

(25) Anbumani, S.; Kakkar, P. Ecotoxicological Effects of Microplastics on Biota: A Review. Environ. Sci. Pollut. Res. 2018, 25 (15), 14373-14396. https://doi.org/10.1007/s11356-018-1999-x.

(26) Barboza, L. G. A.; Dick Vethaak, A.; Lavorante, B. R. B. O.; Lundebye, A.-K.; Guilhermino, L. Marine Microplastic Debris: An Emerging Issue for Food Security, Food Safety and Human Health. Mar. Pollut. Bull. 2018, 133, 336-348. https://doi.org/10.1016/j.marpolbul.2018.05.047.

(27) Choi, J. S.; Jung, Y.-J.; Hong, N.-H.; Hong, S. H.; Park, J.-W. Toxicological Effects of Irregularly Shaped and Spherical Microplastics in a Marine Teleost, the Sheepshead Minnow (Cyprinodon Variegatus). Mar. Pollut. Bull. 2018, 129 (1), 231-240. 
https://doi.org/10.1016/j.marpolbul.2018.02.039.

(28) de Sá, L. C.; Luís, L. G.; Guilhermino, L. Effects of Microplastics on Juveniles of the Common Goby (Pomatoschistus Microps): Confusion with Prey, Reduction of the Predatory Performance and Efficiency, and Possible Influence of Developmental Conditions. Environ. Pollut. 2015, 196, 359362. https://doi.org/10.1016/j.envpol.2014.10.026.

(29) Small, C.; Nicholls, R. J. A Global Analysis of Human Settlement in Coastal Zones. J. Coast. Res. 2003, $19(3), 584-599$.

(30) Kummu, M.; de Moel, H.; Ward, P. J.; Varis, O. How Close Do We Live to Water? A Global Analysis of Population Distance to Freshwater Bodies. PLoS One 2011, 6 (6), e20578. https://doi.org/10.1371/journal.pone.0020578.

(31) Lebreton, L. C. M.; van der Zwet, J.; Damsteeg, J.-W.; Slat, B.; Andrady, A.; Reisser, J. River Plastic Emissions to the World's Oceans. Nat. Commun. 2017, 8, 15611. https://doi.org/10.1038/ncomms15611.

(32) Carr, S. A.; Liu, J.; Tesoro, A. G. Transport and Fate of Microplastic Particles in Wastewater Treatment Plants. Water Res. 2016, 91, 174-182. https://doi.org/10.1016/j.watres.2016.01.002.

(33) Mason, S. A.; Garneau, D.; Sutton, R.; Chu, Y.; Ehmann, K.; Barnes, J.; Fink, P.; Papazissimos, D.; Rogers, D. L. Microplastic Pollution Is Widely Detected in US Municipal Wastewater Treatment Plant Effluent. Environ. Pollut. 2016, 218, 1045-1054. https://doi.org/10.1016/j.envpol.2016.08.056.

(34) Free, C. M.; Jensen, O. P.; Mason, S. A.; Eriksen, M.; Williamson, N. J.; Boldgiv, B. High-Levels of Microplastic Pollution in a Large, Remote, Mountain Lake. Mar. Pollut. Bull. 2014, 85 (1), 156-163. https://doi.org/10.1016/j.marpolbul.2014.06.001.

(35) Baldwin, A. K.; Corsi, S. R.; Mason, S. A. Plastic Debris in 29 Great Lakes Tributaries: Relations to Watershed Attributes and Hydrology. Environ. Sci. Technol. 2016, 50 (19), 10377-10385. https://doi.org/10.1021/acs.est.6b02917.

(36) Eriksen, M.; Maximenko, N.; Thiel, M.; Cummins, A.; Lattin, G.; Wilson, S.; Hafner, J.; Zellers, A.; Rifman, S. Plastic Pollution in the South Pacific Subtropical Gyre. Mar. Pollut. Bull. 2013, 68 (1-2), $71-76$.

(37) Gasperi, J.; Dris, R.; Bonin, T.; Rocher, V.; Tassin, B. Assessment of Floating Plastic Debris in Surface Water along the Seine River. Environ. Pollut. 2014, 195, 163-166. 
https://doi.org/10.1016/j.envpol.2014.09.001.

748

749

750

751

752

753

754

755

756

757

758

759

760

761

762

763

764

765

(38) Lechner, A.; Keckeis, H.; Lumesberger-Loisl, F.; Zens, B.; Krusch, R.; Tritthart, M.; Glas, M.; Schludermann, E. The Danube so Colourful: A Potpourri of Plastic Litter Outnumbers Fish Larvae in Europe's Second Largest River. Environ. Pollut. 2014, 188, 177-181. https://doi.org/http://dx.doi.org/10.1016/j.envpol.2014.02.006.

(39) Dris, R.; Imhof, H.; Sanchez, W.; Gasperi, J.; Galgani, F.; Tassin, B.; Laforsch, C. Beyond the Ocean: Contamination of Freshwater Ecosystems with (Micro-)Plastic Particles. Environ. Chem. 2015, 12 (5), 539-550. https://doi.org/10.1071/EN14172.

(40) O’Connor, J. D.; Mahon, A. M.; Ramsperger, A. F. R. M.; Trotter, B.; Redondo-Hasselerharm, P. E.; Koelmans, A. A.; Lally, H. T.; Murphy, S. Microplastics in Freshwater Biota: A Critical Review of Isolation, Characterization, and Assessment Methods. Glob. Challenges 2019, 1800118. https://doi.org/10.1002/gch2.201800118.

(41) Powers, D. Fish as Model Systems. Science (80-. ). 1989, 246 (4928), 352-358. https://doi.org/10.1126/science.2678474.

(42) Nelson, J. S. Fishes of the World; John Wiley \& Sons, Inc.: Hoboken, 2006.

(43) Markic, A.; Gaertner, J.-C.; Gaertner-Mazouni, N.; Koelmans, A. A. Plastic Ingestion by Marine Fish in the Wild. Crit. Rev. Environ. Sci. Technol. 2019, 1-41.

https://doi.org/10.1080/10643389.2019.1631990.

(44) Jabeen, K.; Su, L.; Li, J.; Yang, D.; Tong, C.; Mu, J.; Shi, H. Microplastics and Mesoplastics in Fish from Coastal and Fresh Waters of China. Environ. Pollut. 2017, 221, 141-149. https://doi.org/http://dx.doi.org/10.1016/j.envpol.2016.11.055.

(45) Murphy, F.; Russell, M.; Ewins, C.; Quinn, B. The Uptake of Macroplastic \& Microplastic by Demersal \& Pelagic Fish in the Northeast Atlantic around Scotland. Mar. Pollut. Bull. 2017, 122 (12), 353-359. https://doi.org/10.1016/j.marpolbul.2017.06.073.

(46) GESAMP. Guidelines or the Monitoring and Assessment of Plastic Litter and Microplastics in the Ocean; Kershaw, P. J., Turra, A., Galgani, F., Eds.; 2019.

(47) Lusher, A. L.; Welden, N. A.; Sobral, P.; Cole, M. Sampling, Isolating and Identifying Microplastics Ingested by Fish and Invertebrates. Anal. Methods 2017, 9 (9), 1346-1360. https://doi.org/10.1039/C6AY02415G. 
(48) Hermsen, E.; Mintenig, S. M.; Besseling, E.; Koelmans, A. A. Quality Criteria for the Analysis of Microplastic in Biota Samples: A Critical Review. Environ. Sci. Technol. 2018, 52 (18), 1023010240. https://doi.org/10.1021/acs.est.8b01611.

(49) Dantas, D. V; Barletta, M.; da Costa, M. F. The Seasonal and Spatial Patterns of Ingestion of Polyfilament Nylon Fragments by Estuarine Drums (Sciaenidae). Environ. Sci. Pollut. Res. 2012, 19 (2), 600-606.

(50) Ramos, J.; Barletta, M.; Costa, M. Ingestion of Nylon Threads by Gerreidae While Using a Tropical Estuary as Foraging Grounds. Aquat. Biol. 2012, 17 (1), 29-34. https://doi.org/10.3354/ab00461.

(51) Vendel, A. L.; Bessa, F.; Alves, V. E. N.; Amorim, A. L. A.; Patrício, J.; Palma, A. R. T. Widespread Microplastic Ingestion by Fish Assemblages in Tropical Estuaries Subjected to Anthropogenic Pressures. Mar. Pollut. Bull. 2017, 117 (1-2), 448-455. https://doi.org/10.1016/j.marpolbul.2017.01.081.

(52) Pegado, T. de S. e S.; Schmid, K.; Winemiller, K. O.; Chelazzi, D.; Cincinelli, A.; Dei, L.; Giarrizzo, T. First Evidence of Microplastic Ingestion by Fishes from the Amazon River Estuary. Mar. Pollut. Bull. 2018, 133, 814-821. https://doi.org/10.1016/J.MARPOLBUL.2018.06.035.

(53) Galgani, F.; Hanke, G.; Werner, S.; Oosterbaan, L.; Nilsson, P.; Fleet, D.; Kinsey, S.; Thompson, R. C.; van Franeker, J.; Vlachogianna, T.; et al. Guidance on Monitoring of Marine Litter in European Seas; 2013.

(54) ICES. OSPAR Request on Development of a Common Monitoring Protocol for Plastic Particles in Fish Stomachs and Selected Shellfish on the Basis of Existing Fish Disease Surveys; 2015.

(55) Van Franeker, J.; Meijboom, A. Litter NSV, Marine Litter Monitoring by Northern Fulmars; a Pilot Study; Wageningen, 2002.

(56) Pazos, R. S.; Maiztegui, T.; Colautti, D. C.; Paracampo, A. H.; Gómez, N. Microplastics in Gut Contents of Coastal Freshwater Fish from Río de La Plata Estuary. Mar. Pollut. Bull. 2017, 122 (12), 85-90. https://doi.org/10.1016/j.marpolbul.2017.06.007.

(57) Collard, F.; Gasperi, J.; Gilbert, B.; Eppe, G.; Azimi, S.; Rocher, V.; Tassin, B. Anthropogenic Particles in the Stomach Contents and Liver of the Freshwater Fish Squalius Cephalus. Sci. Total Environ. 2018, 643. https://doi.org/10.1016/j.scitotenv.2018.06.313.

(58) Dehaut, A.; Cassone, A.-L.; Frère, L.; Hermabessiere, L.; Himber, C.; Rinnert, E.; Rivière, G.; 
Lambert, C.; Soudant, P.; Huvet, A.; et al. Microplastics in Seafood: Benchmark Protocol for Their Extraction and Characterization. Environ. Pollut. 2016, 215, 223-233. https://doi.org/10.1016/j.envpol.2016.05.018.

(59) Zhang, K.; Xiong, X.; Hu, H.; Wu, C.; Bi, Y.; Wu, Y.; Zhou, B.; Lam, P. K. S.; Liu, J. Occurrence and Characteristics of Microplastic Pollution in Xiangxi Bay of Three Gorges Reservoir, China. Environ. Sci. Technol. 2017, 51 (7), 3794-3801. https://doi.org/10.1021/acs.est.7b00369.

(60) Claessens, M.; Van Cauwenberghe, L.; Vandegehuchte, M. B.; Janssen, C. R. New Techniques for the Detection of Microplastics in Sediments and Field Collected Organisms. Mar. Pollut. Bull. 2013, $70(1-2), 227-233$.

(61) Avio, C. G.; Gorbi, S.; Regoli, F. Experimental Development of a New Protocol for Extraction and Characterization of Microplastics in Fish Tissues: First Observations in Commercial Species from Adriatic Sea. Mar. Environ. Res. 2015, 111, 18-26. https://doi.org/10.1016/j.marenvres.2015.06.014.

(62) Catarino, A. I.; Thompson, R.; Sanderson, W.; Henry, T. B. Development and Optimization of a Standard Method for Extraction of Microplastics in Mussels by Enzyme Digestion of Soft Tissues. Environ. Toxicol. Chem. 2017, 36 (4), 947-951. https://doi.org/10.1002/etc.3608.

(63) Cole, M.; Webb, H.; Lindeque, P. K.; Fileman, E. S.; Halsband, C.; Galloway, T. S. Isolation of Microplastics in Biota-Rich Seawater Samples and Marine Organisms. Sci. Rep. 2014, 4, 4528. https://doi.org/10.1038/srep04528.

(64) Railo, S.; Talvitie, J.; Setälä, O.; Koistinen, A.; Lehtiniemi, M. Application of an Enzyme Digestion Method Reveals Microlitter in Mytilus Trossulus at a Wastewater Discharge Area. Mar. Pollut. Bull. 2018, 130, 206-214. https://doi.org/10.1016/j.marpolbul.2018.03.022.

(65) von Friesen, L. W.; Granberg, M. E.; Hassellöv, M.; Gabrielsen, G. W.; Magnusson, K. An Efficient and Gentle Enzymatic Digestion Protocol for the Extraction of Microplastics from Bivalve Tissue. Mar. Pollut. Bull. 2019, 142, 129-134. https://doi.org/10.1016/j.marpolbul.2019.03.016.

(66) Tagg, A. S.; Harrison, J. P.; Ju-Nam, Y.; Sapp, M.; Bradley, E. L.; Sinclair, C. J.; Ojeda, J. J. Fenton's Reagent for the Rapid and Efficient Isolation of Microplastics from Wastewater. Chem. Commun. 2017, 53 (2), 372-375. https://doi.org/10.1039/C6CC08798A.

(67) Horton, A. A.; Jürgens, M. D.; Lahive, E.; van Bodegom, P. M.; Vijver, M. G. The Influence of Exposure and Physiology on Microplastic Ingestion by the Freshwater Fish Rutilus Rutilus (Roach) 
in the River Thames, UK. Environ. Pollut. 2018, 236, 188-194. https://doi.org/10.1016/J.ENVPOL.2018.01.044.

(68) Collard, F.; Gilbert, B.; Eppe, G.; Parmentier, E.; Das, K. Detection of Anthropogenic Particles in Fish Stomachs: An Isolation Method Adapted to Identification by Raman Spectroscopy. Arch. Environ. Contam. Toxicol. 2015, 69 (3), 331-339. https://doi.org/10.1007/s00244-015-0221-0.

(69) Kühn, S.; van Werven, B.; van Oyen, A.; Meijboom, A.; Bravo Rebolledo, E. L.; van Franeker, J. A. The Use of Potassium Hydroxide $(\mathrm{KOH})$ Solution as a Suitable Approach to Isolate Plastics Ingested by Marine Organisms. Mar. Pollut. Bull. 2017, 115 (1-2), 86-90. https://doi.org/10.1016/j.marpolbul.2016.11.034.

(70) Barrows, A. P. W.; Cathey, S. E.; Petersen, C. W. Marine Environment Microfiber Contamination: Global Patterns and the Diversity of Microparticle Origins. Environ. Pollut. 2018, 237, $275-284$. https://doi.org/10.1016/J.ENVPOL.2018.02.062.

(71) Darbra, R. M.; Gonzalez Dan, J. R.; Casal, J.; Agueda, A.; Capri, E.; Fait, G.; Schuhmacher, M.; Nadal, M.; Rovira, J.; Grundmann, V.; et al. Additives in the Textile Industry. In Global Risk-Based Management of Chemical Additives I. Production, usage, and environmental occurrence; Bilitewski, B., Darbra, R. M., Barceló, D., Eds.; The Handbook of Environmental Chemistry; Springer Berlin Heidelberg: Berlin, Heidelberg, 2011; Vol. 18, p 290. https://doi.org/10.1016/0143-1471(82)90111-8.

(72) Robinson, T.; McMullan, G.; Marchant, R.; Nigam, P. Remediation of Dyes in Textile Effluent: A Critical Review on Current Treatment Technologies with a Proposed Alternative. Bioresour. Technol. 2001, 77 (3), 247-255. https://doi.org/10.1016/S0960-8524(00)00080-8.

(73) Pokharia, A.; Singh, S. Toxicological Effect of Textile Dyes and Their Metabolites: A Review. Curr. Trends Biotechnol. Chem. Res. 2015, 5 (1), 11-17.

(74) Remy, F.; Collard, F.; Gilbert, B.; Compère, P.; Eppe, G.; Lepoint, G. When Microplastic Is Not Plastic: The Ingestion of Artificial Cellulose Fibers by Macrofauna Living in Seagrass Macrophytodetritus. Environ. Sci. Technol. 2015, 49 (18), 11158-11166. https://doi.org/10.1021/acs.est.5b02005.

(75) Andrady, A. L. Microplastics in the Marine Environment. Mar. Pollut. Bull. 2011, 62 (8), $1596-1605$. https://doi.org/10.1016/j.marpolbul.2011.05.030.

(76) Renner, G.; Schmidt, T. C.; Schram, J. Analytical Methodologies for Monitoring 
Micro(Nano)Plastics: Which Are Fit for Purpose? Curr. Opin. Environ. Sci. Heal. 2018, 1, 55-61. https://doi.org/10.1016/j.coesh.2017.11.001.

(77) Collard, F.; Gilbert, B.; Eppe, G.; Roos, L.; Compère, P.; Das, K.; Parmentier, E. Morphology of the Filtration Apparatus of Three Planktivorous Fishes and Relation with Ingested Anthropogenic Particles. Mar. Pollut. Bull. 2017, 116 (1-2), 182-191. https://doi.org/10.1016/j.marpolbul.2016.12.067.

(78) Löder, M. G. J.; Kuczera, M.; Mintenig, S.; Lorenz, C.; Gerdts, G. Focal Plane Array Detector-Based Micro-Fourier-Transform Infrared Imaging for the Analysis of Microplastics in Environmental Samples. Environ. Chem. 2015, 12 (5), 563. https://doi.org/10.1071/EN14205.

(79) Song, Y. K.; Hong, S. H.; Jang, M.; Han, G. M.; Rani, M.; Lee, J.; Shim, W. J. A Comparison of Microscopic and Spectroscopic Identification Methods for Analysis of Microplastics in Environmental Samples. Mar. Pollut. Bull. 2015, 93 (1-2), 202-209. https://doi.org/10.1016/j.marpolbul.2015.01.015.

(80) GESAMP. Sources, Fate and Effects of Microplastics in the Marine Environment: Part Two of a Global Assessment; Kershaw, P. J., Rochman, C. M., Eds.; Rep. Stud. GESAMP No. 93, 2016.

(81) Roch, S.; Walter, T.; Ittner, L. D.; Friedrich, C.; Brinker, A. A Systematic Study of the Microplastic Burden in Freshwater Fishes of South-Western Germany - Are We Searching at the Right Scale? Sci. Total Environ. 2019, 689, 1001-1011. https://doi.org/10.1016/j.scitotenv.2019.06.404.

(82) Vandermeersch, G.; Van Cauwenberghe, L.; Janssen, C. R.; Marques, A.; Granby, K.; Fait, G.; Kotterman, M. J. J.; Diogène, J.; Bekaert, K.; Robbens, J.; et al. A Critical View on Microplastic Quantification in Aquatic Organisms. Environ. Res. 2015, 143, 46-55. https://doi.org/10.1016/j.envres.2015.07.016.

(83) Dümichen, E.; Barthel, A.-K.; Braun, U.; Bannick, C. G.; Brand, K.; Jekel, M.; Senz, R. Analysis of Polyethylene Microplastics in Environmental Samples, Using a Thermal Decomposition Method. Water Res. 2015, 85, 451-457. https://doi.org/10.1016/j.watres.2015.09.002.

(84) Käppler, A.; Fischer, D.; Oberbeckmann, S.; Schernewski, G.; Labrenz, M.; Eichhorn, K.-J.; Voit, B. Analysis of Environmental Microplastics by Vibrational Microspectroscopy: FTIR, Raman or Both? Anal. Bioanal. Chem. 2016, 408 (29), 8377-8391. https://doi.org/10.1007/s00216-016-9956-3.

(85) Araujo, C. F.; Nolasco, M. M.; Ribeiro, A. M. P.; Ribeiro-Claro, P. J. A. Identification of 
Microplastics Using Raman Spectroscopy: Latest Developments and Future Prospects. Water Res. 2018, 142, 426-440. https://doi.org/10.1016/J.WATRES.2018.05.060.

(86) Steer, M.; Cole, M.; Thompson, R. C.; Lindeque, P. K. Microplastic Ingestion in Fish Larvae in the Western English Channel. Environ. Pollut. 2017, 226, 250-259. https://doi.org/10.1016/j.envpol.2017.03.062.

(87) Bessa, F.; Barría, P.; Neto, J. M.; Frias, J. P. G. L.; Otero, V.; Sobral, P.; Marques, J. C. Occurrence of Microplastics in Commercial Fish from a Natural Estuarine Environment. Mar. Pollut. Bull. 2018, 128, 575-584. https://doi.org/10.1016/j.marpolbul.2018.01.044.

(88) Wieczorek, A. M.; Morrison, L.; Croot, P. L.; Allcock, A. L.; MacLoughlin, E.; Savard, O.; Brownlow, H.; Doyle, T. K. Frequency of Microplastics in Mesopelagic Fishes from the Northwest Atlantic. Front. Mar. Sci. 2018, 5. https://doi.org/10.3389/fmars.2018.00039.

(89) Watts, A. J. R.; Lewis, C.; Goodhead, R. M.; Beckett, S. J.; Moger, J.; Tyler, C. R.; Galloway, T. S. Uptake and Retention of Microplastics by the Shore Crab Carcinus Maenas. Environ. Sci. Technol. 2014, 48 (15), 8823-8830.

(90) Grigorakis, S.; Mason, S. A.; Drouillard, K. G. Determination of the Gut Retention of Plastic Microbeads and Microfibers in Goldfish (Carassius Auratus). Chemosphere 2017, 169, 233-238. https://doi.org/http://dx.doi.org/10.1016/j.chemosphere.2016.11.055.

(91) McNeish, R. E.; Kim, L. H.; Barrett, H. A.; Mason, S. A.; Kelly, J. J.; Hoellein, T. J. Microplastic in Riverine Fish Is Connected to Species Traits. Sci. Rep. 2018, 8 (1), 11639. https://doi.org/10.1038/s41598-018-29980-9.

(92) Wesch, C.; Elert, A. M.; Wörner, M.; Braun, U.; Klein, R.; Paulus, M. Assuring Quality in Microplastic Monitoring: About the Value of Clean-Air Devices as Essentials for Verified Data. Sci. Rep. 2017, 7 (1), 5424. https://doi.org/10.1038/s41598-017-05838-4.

(93) Kosuth, M.; Mason, S. A.; Wattenberg, E. V. Anthropogenic Contamination of Tap Water, Beer, and Sea Salt. PLoS One 2018, 13 (4), e0194970. https://doi.org/10.1371/journal.pone.0194970.

(94) Yang, D.; Shi, H.; Li, L.; Li, J.; Jabeen, K.; Kolandhasamy, P. Microplastic Pollution in Table Salts from China. Environ. Pollut. 2015, 49, 13622-13627. https://doi.org/10.1021/acs.est.5b03163.

(95) Iñiguez, M. E.; Conesa, J. A.; Fullana, A. Microplastics in Spanish Table Salt. Sci. Rep. 2017, 7 (1), 8620. https://doi.org/10.1038/s41598-017-09128-X. 
921 (96) Campbell, S. H.; Williamson, P. R.; Hall, B. D. Microplastics in the Gastrointestinal Tracts of Fish and the Water from an Urban Prairie Creek. FACETS 2017, 2 (1), 395-409. https://doi.org/10.1139/facets-2017-0008.

Possatto, F. E.; Barletta, M.; Costa, M. F.; do Sul, J. A. I.; Dantas, D. V. Plastic Debris Ingestion by Marine Catfish: An Unexpected Fisheries Impact. Mar. Pollut. Bull. 2011, 62 (5), 1098-1102. https://doi.org/10.1016/j.marpolbul.2011.01.036.

(98) Sanchez, W.; Bender, C.; Porcher, J.-M. Wild Gudgeons (Gobio Gobio) from French Rivers Are Contaminated by Microplastics: Preliminary Study and First Evidence. Environ. Res. 2014, 128, 98100. https://doi.org/10.1016/j.envres.2013.11.004.

(99) Biginagwa, F. J.; Mayoma, B. S.; Shashoua, Y.; Syberg, K.; Khan, F. R. First Evidence of Microplastics in the African Great Lakes: Recovery from Lake Victoria Nile Perch and Nile Tilapia. J. Great Lakes Res. 2016, 42 (1). https://doi.org/10.1016/j.jglr.2015.10.012.

(100) Faure, F.; Saini, C.; Potter, G.; Galgani, F.; de Alencastro, L. F.; Hagmann, P. An Evaluation of Surface Micro- and Mesoplastic Pollution in Pelagic Ecosystems of the Western Mediterranean Sea. Environ. Sci. Pollut. Res. Int. 2015. https://doi.org/10.1007/s11356-015-4453-3.

(101) Phillips, M. B.; Bonner, T. H. Occurrence and Amount of Microplastic Ingested by Fishes in Watersheds of the Gulf of Mexico. Mar. Pollut. Bull. 2015. https://doi.org/10.1016/j.marpolbul.2015.08.041.

(102) Ferreira, G. V. B.; Barletta, M.; Lima, A. R. A.; Dantas, D. V.; Justino, A. K. S.; Costa, M. F. Plastic Debris Contamination in the Life Cycle of Acoupa Weakfish ( Cynoscion Acoupa ) in a Tropical Estuary. ICES J. Mar. Sci. J. du Cons. 2016, 73 (10), 2695-2707. https://doi.org/10.1093/icesjms/fsw108.

(103) Peters, C. A.; Bratton, S. P. Urbanization Is a Major Influence on Microplastic Ingestion by Sunfish in the Brazos River Basin, Central Texas, USA. Environ. Pollut. 2016, 210, 380-387. https://doi.org/10.1016/j.envpol.2016.01.018.

(104) McGoran, A. R.; Clark, P. F.; Morritt, D. Presence of Microplastic in the Digestive Tracts of European Flounder, Platichthys Flesus, and European Smelt, Osmerus Eperlanus, from the River Thames. Environ. Pollut. 2017, 220, 744-751. https://doi.org/10.1016/j.envpol.2016.09.078.

(105) Silva-Cavalcanti, J. S.; Silva, J. D. B.; França, E. J. de; Araújo, M. C. B. de; Gusmão, F. 
Microplastics Ingestion by a Common Tropical Freshwater Fishing Resource. Environ. Pollut. 2017, 221, 218-226. https://doi.org/10.1016/j.envpol.2016.11.068.

(106) Abbasi, S.; Soltani, N.; Keshavarzi, B.; Moore, F.; Turner, A.; Hassanaghaei, M. Microplastics in Different Tissues of Fish and Prawn from the Musa Estuary, Persian Gulf. Chemosphere 2018, 205, 80-87. https://doi.org/10.1016/j.chemosphere.2018.04.076.

(107) Xiong, X.; Zhang, K.; Chen, X.; Shi, H.; Luo, Z.; Wu, C. Sources and Distribution of Microplastics in China's Largest Inland Lake - Qinghai Lake. Environ. Pollut. 2018, 235, 899-906. https://doi.org/10.1016/j.envpol.2017.12.081.

(108) Andrade, M. C.; Winemiller, K. O.; Barbosa, P. S.; Fortunati, A.; Chelazzi, D.; Cincinelli, A.; Giarrizzo, T. First Account of Plastic Pollution Impacting Freshwater Fishes in the Amazon: Ingestion of Plastic Debris by Piranhas and Other Serrasalmids with Diverse Feeding Habits. Environ. Pollut. 2019, 244, 766-773. https://doi.org/10.1016/j.envpol.2018.10.088.

(109) Slootmaekers, B.; Catarci Carteny, C.; Belpaire, C.; Saverwyns, S.; Fremout, W.; Blust, R.; Bervoets, L. Microplastic Contamination in Gudgeons (Gobio Gobio) from Flemish Rivers (Belgium). Environ. Pollut. 2019, 244, 675-684. https://doi.org/10.1016/j.envpol.2018.09.136.

(110) Yuan, W.; Liu, X.; Wang, W.; Di, M.; Wang, J. Microplastic Abundance, Distribution and Composition in Water, Sediments, and Wild Fish from Poyang Lake, China. Ecotoxicol. Environ. Saf. 2019, 170, 180-187. https://doi.org/10.1016/j.ecoenv.2018.11.126.

(111) Su, L.; Deng, H.; Li, B.; Chen, Q.; Pettigrove, V.; Wu, C.; Shi, H. The Occurrence of Microplastic in Specific Organs in Commercially Caught Fishes from Coast and Estuary Area of East China. $J$. Hazard. Mater. 2019, 365, 716-724. https://doi.org/10.1016/j.jhazmat.2018.11.024.

(112) Ferreira, G. V. B.; Barletta, M.; Lima, A. R. A. Use of Estuarine Resources by Top Predator Fishes. How Do Ecological Patterns Affect Rates of Contamination by Microplastics? Sci. Total Environ. 2019, 655, 292-304. https://doi.org/10.1016/j.scitotenv.2018.11.229.

(113) Arias, A. H.; Ronda, A. C.; Oliva, A. L.; Marcovecchio, J. E. Evidence of Microplastic Ingestion by Fish from the Bahía Blanca Estuary in Argentina, South America. Bull. Environ. Contam. Toxicol. 2019. https://doi.org/10.1007/s00128-019-02604-2.

(114) Su, L.; Nan, B.; Hassell, K. L.; Craig, N. J.; Pettigrove, V. Microplastics Biomonitoring in Australian Urban Wetlands Using a Common Noxious Fish (Gambusia Holbrooki). Chemosphere 2019, 228, 
65-74. https://doi.org/10.1016/j.chemosphere.2019.04.114.

(115) Hidalgo-Ruz, V.; Gutow, L.; Thompson, R. C.; Thiel, M. Microplastics in the Marine Environment: A Review of the Methods Used for Identification and Quantification. Environ. Sci. Technol. 2012, 46 (6), 3060-3075.

(116) Zobkov, M. B.; Esiukova, E. E. Microplastics in a Marine Environment: Review of Methods for Sampling, Processing, and Analyzing Microplastics in Water, Bottom Sediments, and Coastal Deposits. Oceanology 2018, 58 (1), 137-143. https://doi.org/10.1134/S0001437017060169.

(117) Rodrigues, M. O.; Abrantes, N.; Gonçalves, F. J. M.; Nogueira, H.; Marques, J. C.; Gonçalves, A. M. M. Spatial and Temporal Distribution of Microplastics in Water and Sediments of a Freshwater System (Antuã River, Portugal). Sci. Total Environ. 2018, 633, 1549-1559. https://doi.org/10.1016/j.scitotenv.2018.03.233.

(118) Lin, L.; Zuo, L.-Z.; Peng, J.-P.; Cai, L.-Q.; Fok, L.; Yan, Y.; Li, H.-X.; Xu, X.-R. Occurrence and Distribution of Microplastics in an Urban River: A Case Study in the Pearl River along Guangzhou City, China. Sci. Total Environ. 2018, 644, 375-381. https://doi.org/10.1016/j.scitotenv.2018.06.327.

(119) Su, L.; Xue, Y.; Li, L.; Yang, D.; Kolandhasamy, P.; Li, D.; Shi, H. Microplastics in Taihu Lake, China. Environ. Pollut. 2016, 216, 711-719. https://doi.org/10.1016/j.envpol.2016.06.036.

(120) Ballent, A.; Corcoran, P. L.; Madden, O.; Helm, P. A.; Longstaffe, F. J. Sources and Sinks of Microplastics in Canadian Lake Ontario Nearshore, Tributary and Beach Sediments. Mar. Pollut. Bull. 2016, 110 (1), 383-395. https://doi.org/10.1016/j.marpolbul.2016.06.037.

(121) McCormick, A.; Hoellein, T. J.; Mason, S. A.; Schluep, J.; Kelly, J. J. Microplastic Is an Abundant and Distinct Microbial Habitat in an Urban River. Environ. Sci. Technol. 2014, 48 (20), 1186311871. https://doi.org/10.1021/es503610r.

(122) Claessens, M.; Meester, S. D.; Landuyt, L. V; Clerck, K. D.; Janssen, C. R. Occurrence and Distribution of Microplastics in Marine Sediments along the Belgian Coast. Mar. Pollut. Bull. 2011, 62 (10), 2199-2204.

(123) Vianello, A.; Boldrin, A.; Guerriero, P.; Moschino, V.; Rella, R.; Sturaro, A.; Da Ros, L. Microplastic Particles in Sediments of Lagoon of Venice, Italy: First Observations on Occurrence, Spatial Patterns and Identification. Estuar. Coast. Shelf Sci. 2013, 130, 54-61. https://doi.org/10.1016/j.ecss.2013.03.022. 
1008

1009

1010

1011

1012

1013

1014

1015

1016

1017

1018

1019

1020

1021

1022

1023

1024

1025

1026

1027

1028

1029

1030

1031

1032

1033

1034

1035

1036

(124) Kim, S. W.; Chae, Y.; Kim, D.; An, Y.-J. Zebrafish Can Recognize Microplastics as Inedible Materials: Quantitative Evidence of Ingestion Behavior. Sci. Total Environ. 2019, 649, 156-162. https://doi.org/10.1016/j.scitotenv.2018.08.310.

(125) Vroom, R. J. E.; Koelmans, A. A.; Besseling, E.; Halsband, C. Aging of Microplastics Promotes Their Ingestion by Marine Zooplankton. Environ. Pollut. 2017, 231, Part, 987-996. https://doi.org/https://doi.org/10.1016/j.envpol.2017.08.088.

(126) Savoca, M. S.; Wohlfeil, M. E.; Ebeler, S. E.; Nevitt, G. A. Marine Plastic Debris Emits a Keystone Infochemical for Olfactory Foraging Seabirds. Sci. $A d v$. 2016, 2 (11).

(127) Savoca, M. S.; Tyson, C. W.; McGill, M.; Slager, C. J. Odours from Marine Plastic Debris Induce Food Search Behaviours in a Forage Fish. Proc. R. Soc. B Biol. Sci. 2017, 284 (1860), 20171000. https://doi.org/10.1098/rspb.2017.1000.

(128) Cheung, P. K.; Cheung, L. T. O.; Fok, L. Seasonal Variation in the Abundance of Marine Plastic Debris in the Estuary of a Subtropical Macro-Scale Drainage Basin in South China. Sci. Total Environ. 2016, 562, 658-665. https://doi.org/10.1016/j.scitotenv.2016.04.048.

(129) Goldberg, E. D. Plasticizing the Seafloor: An Overview. Environ. Technol. 1997, 18 (2), 195-201. https://doi.org/10.1080/09593331808616527.

(130) Lusher, A. L.; McHugh, M.; Thompson, R. C. Occurrence of Microplastics in the Gastrointestinal Tract of Pelagic and Demersal Fish from the English Channel. Mar. Pollut. Bull. 2013, 67 (1-2), 94 99.

(131) Chagnon, C.; Thiel, M.; Antunes, J.; Ferreira, J. L.; Sobral, P.; Ory, N. C. Plastic Ingestion and Trophic Transfer between Easter Island Flying Fish (Cheilopogon Rapanouiensis) and Yellowfin Tuna (Thunnus Albacares) from Rapa Nui (Easter Island). Environ. Pollut. 2018, 243, 127-133. https://doi.org/10.1016/j.envpol.2018.08.042.

(132) Bravo Rebolledo, E. L.; Van Franeker, J. A.; Jansen, O. E.; Brasseur, S. M. J. M. Plastic Ingestion by Harbour Seals (Phoca Vitulina) in The Netherlands. Mar. Pollut. Bull. 2013, 67 (1-2), 200-202. https://doi.org/10.1016/j.marpolbul.2012.11.035.

(133) Donohue, M. J.; Masura, J.; Gelatt, T.; Ream, R.; Baker, J. D.; Faulhaber, K.; Lerner, D. T. Evaluating Exposure of Northern Fur Seals, Callorhinus Ursinus, to Microplastic Pollution through Fecal Analysis. Mar. Pollut. Bull. 2019, 138, 213-221. 
https://doi.org/10.1016/j.marpolbul.2018.11.036.

(134) Clements, K. D.; Choat, J. H. Influence of Season, Ontogeny and Tide on the Diet of the Temperate Marine Herbivorous Fish Odax Pullus (Odacidae). Mar. Biol. 1993, 117 (2), 213-220. https://doi.org/10.1007/BF00345665.

(135) King, A. J. Ontogenetic Dietary Shifts of Fishes in an Australian Floodplain River. Mar. Freshw. Res. 2005, 56 (2), 215. https://doi.org/10.1071/MF04117.

(136) Demain, D. K.; Gallego, A.; Jaworski, A.; Priede, I. G.; Jones, E. G. Diet and Feeding Niches of Juvenile Gadus Morhua, Melanogrammus Aeglefinus and Merlangius Merlangus during the Settlement Transition in the Northern North Sea. J. Fish Biol. 2011, 79 (1), 89-111. https://doi.org/10.1111/j.1095-8649.2011.02997.x.

(137) Nunn, A. D.; Tewson, L. H.; Cowx, I. G. The Foraging Ecology of Larval and Juvenile Fishes. Rev. Fish Biol. Fish. 2012, 22 (2), 377-408. https://doi.org/10.1007/s11160-011-9240-8.

(138) Anastasopoulou, A.; Mytilineou, C.; Smith, C. J.; Papadopoulou, K. N. Plastic Debris Ingested by Deep-Water Fish of the Ionian Sea (Eastern Mediterranean). Deep. Res. Part I Oceanogr. Res. Pap. 2013, 74, 11-13.

(139) Lazzaro, X. A Review of Planktivorous Fishes: Their Evolution, Feeding Behaviours, Selectivities, and Impacts. Hydrobiologia 1987, 146 (2), 97-167. https://doi.org/10.1007/BF00008764.

(140) Ory, N. C.; Gallardo, C.; Lenz, M.; Thiel, M. Capture, Swallowing, and Egestion of Microplastics by a Planktivorous Juvenile Fish. Environ. Pollut. 2018, 240, 566-573. https://doi.org/10.1016/J.ENVPOL.2018.04.093.

(141) Carson, H. S. The Incidence of Plastic Ingestion by Fishes: From the Prey's Perspective. Mar. Pollut. Bull. 2013.

(142) Lima, A. R. A.; Costa, M. F.; Barletta, M. Distribution Patterns of Microplastics within the Plankton of a Tropical Estuary. Environ. Res. 2014, 132, 146-155. https://doi.org/10.1016/j.envres.2014.03.031.

(143) van der Oost, R.; Beyer, J.; Vermeulen, N. P. . Fish Bioaccumulation and Biomarkers in Environmental Risk Assessment: A Review. Environ. Toxicol. Pharmacol. 2003, 13 (2), 57-149. https://doi.org/10.1016/S1382-6689(02)00126-6.

(144) Browne, M. A.; Crump, P.; Niven, S. J.; Teuten, E.; Tonkin, A.; Galloway, T.; Thompson, R. 
Accumulation of Microplastic on Shorelines Worldwide: Sources and Sinks. Environ. Sci. Technol. 2011, 45 (21), 9175-9179. https://doi.org/10.1021/es201811s.

(145) Salvador Cesa, F.; Turra, A.; Baruque-Ramos, J. Synthetic Fibers as Microplastics in the Marine Environment: A Review from Textile Perspective with a Focus on Domestic Washings. Sci. Total Environ. 2017, 598, 1116-1129. https://doi.org/10.1016/j.scitotenv.2017.04.172.

(146) Kase, R.; Korkaric, M.; Werner, I.; Ågerstrand, M. Criteria for Reporting and Evaluating Ecotoxicity Data (CRED): Comparison and Perception of the Klimisch and CRED Methods for Evaluating Reliability and Relevance of Ecotoxicity Studies. Environ. Sci. Eur. 2016, 28 (1), 7. https://doi.org/10.1186/s12302-016-0073-X.

(147) Collard, F.; Gilbert, B.; Compère, P.; Eppe, G.; Das, K.; Jauniaux, T.; Parmentier, E. Microplastics in Livers of European Anchovies (Engraulis Encrasicolus, L.). Environ. Pollut. 2017, 229, 1000-1005. https://doi.org/10.1016/j.envpol.2017.07.089.

(148) Ribeiro, F.; Garcia, A. R.; Pereira, B. P.; Fonseca, M.; Mestre, N. C.; Fonseca, T. G.; Ilharco, L. M.; Bebianno, M. J. Microplastics Effects in Scrobicularia Plana. Mar. Pollut. Bull. 2017, 122 (1-2), 379-391. https://doi.org/10.1016/j.marpolbul.2017.06.078.

(149) Khan, M. B.; Prezant, R. S. Microplastic Abundances in a Mussel Bed and Ingestion by the Ribbed Marsh Mussel Geukensia Demissa. Mar. Pollut. Bull. 2018, 130, 67-75. https://doi.org/10.1016/j.marpolbul.2018.03.012.

(150) Rochman, C. M.; Browne, M. A.; Underwood, A. J.; van Franeker, J. A.; Thompson, R. C.; AmaralZettler, L. A. The Ecological Impacts of Marine Debris: Unraveling the Demonstrated Evidence from What Is Perceived. Ecology 2016, 97 (2), 302-312. https://doi.org/10.1890/14-2070.1.

(151) Mazurais, D.; Ernande, B.; Quazuguel, P.; Severe, A.; Huelvan, C.; Madec, L.; Mouchel, O.; Soudant, P.; Robbens, J.; Huvet, A.; et al. Evaluation of the Impact of Polyethylene Microbeads Ingestion in European Sea Bass (Dicentrarchus Labrax) Larvae. Mar. Environ. Res. 2015, 112, 78 85. https://doi.org/10.1016/j.marenvres.2015.09.009.

(152) de Sá, L. C.; Oliveira, M.; Ribeiro, F.; Rocha, T. L.; Futter, M. N. Studies of the Effects of Microplastics on Aquatic Organisms: What Do We Know and Where Should We Focus Our Efforts in the Future? Sci. Total Environ. 2018, 645, 1029-1039. https://doi.org/10.1016/j.scitotenv.2018.07.207. 
1095 (153) Crain, D. A.; Eriksen, M.; Iguchi, T.; Jobling, S.; Laufer, H.; LeBlanc, G. A.; Guillette, L. J. An 1096 Ecological Assessment of Bisphenol-A: Evidence from Comparative Biology. Reprod. Toxicol. 2007, 24 (2), 225-239. https://doi.org/10.1016/j.reprotox.2007.05.008.

(154) Oehlmann, J.; Schulte-Oehlmann, U.; Kloas, W.; Jagnytsch, O.; Lutz, I.; Kusk, K. O.; Wollenberger, L.; Santos, E. M.; Paull, G. C.; Van Look, K. J. W.; et al. A Critical Analysis of the Biological Impacts of Plasticizers on Wildlife. Philos. Trans. R. Soc. Lond. B. Biol. Sci. 2009, 364 (1526), 20472062. https://doi.org/10.1098/rstb.2008.0242.

(155) Johnson, L. L.; Anulacion, B. F.; Arkoosh, M. R.; Burrows, D. G.; da Silva, D. A. M.; Dietrich, J. P.; Myers, M. S.; Spromberg, J.; Ylitalo, G. M. Effects of Legacy Persistent Organic Pollutants (POPs) in Fish—Current and Future Challenges. In Organic Chemical Toxicology of fishes; Tierney, K. B., 